Spring 6-5-2018

\title{
What Should We Do After Work? Automation and Employment Law
}

Cynthia L. Estlund

Follow this and additional works at: https://scholarship.law.unc.edu/aidr_collection

Part of the Labor and Employment Law Commons 


\section{NEW YORK UNIVERSITY SCHOOL OF LAW}

PUBLIC LAW \& LEGAL THEORY RESEARCH PAPER SERIES WORKING PAPER NO. 17-28

LAW \& ECONOMICS RESEARCH PAPER SERIES

WORKING PAPER NO. 17-26

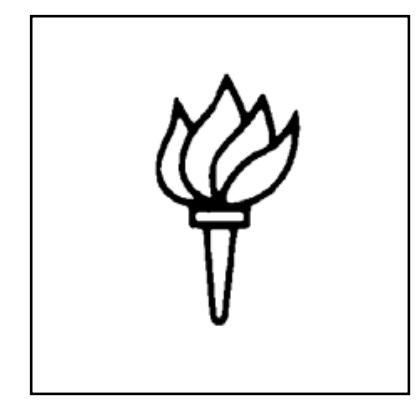

What Should We Do After Work? Automation and Employment Law

Cynthia Estlund

June 2018 


\title{
What Should We Do After Work? Automation, Fissuring, and the Law of Work
}

\author{
Cynthia Estlund, NYU School of Law \\ $($ draft $-5 / 31 / 18)$
}

\begin{abstract}
Will advances in robotics, artificial intelligence, and machine learning put vast swaths of the labor force out of work or into fierce competition for the jobs that remain? Or, as in the past, will new jobs absorb workers displaced by automation? These hotly debated questions have profound implications for the fortress of rights and benefits that the law of work has constructed on the foundation of the employment relationship. This Article charts a path for reforming the law of work in the face of both justified anxiety and uncertainty about the future impact of automation on jobs.

Automation is driven largely by the same forces that drive firms' decisions about "fissuring," or replacing employees with outside contractors. Fissuring has already transformed the landscape of work and contributed to weaker labor standards and growing inequality. A sensible response to automation should have in mind the adjacent problem of fissuring, and vice versa. Unfortunately, the dominant legal responses to fissuring — which aim to extend firms' legal responsibility for the workers whose labor they rely on-do not meet the distinctive challenge of automation, and even modestly exacerbate it. Automation offers the ultimate exit from the costs and risks associated with human labor. As technology becomes an ever-more-capable and cost-effective substitute for buman workers, it enables firms to circumvent prevailing legal strategies for protecting workers and shoring up the fortress of employment.

The question is how to protect workers' rights and entitlements while reducing firms' incentive both to replace employees with contractors and to replace buman workers with machines. The answer, I argue, lies in separating the issue of what workers' entitlements should be from the issue of where their economic burdens should fall. Some worker rights and entitlements necessarily entail employer duties and burdens. But for those that do not, we should look for ways to shift their costs beyond employer payrolls, or to extend the entitlements themselves beyond employment. The existing fortress of employment-based rights and benefits is under assault from fissuring and automation; it is failing to protect those who remain outside its walls, and erecting barriers to some who seek to enter. We need to dismantle some of its fortifications and construct a broader foundation of economic security for all, including those who cannot or do not make their living through steady employment.
\end{abstract}




\section{Introduction}

Three major threats to American jobs have grabbed headlines in recent years. The first is the migration of manufacturing jobs to China, perhaps best exemplified by Foxconn, the Taiwanese firm that employs over a million Chinese workers in the production of iPhones, iPads, and other consumer electronics. To labor law cognoscenti, the outsourcing of manufacturing to China, and the feared "race to the bottom" in labor standards, is mostly yesterday's news. Since 2015, they have been more preoccupied with the rise of platform-based "gig" work in place of real jobs, as epitomized by Uber's treatment of its drivers as independent contractors rather than employees.

Yet both of these threats to American jobs and workers arguably pale beside the threat of automation. If Uber has its way, its drivers will soon go the way of lamplighters, replaced by self-driving vehicles. ${ }^{1}$ And if Foxconn is representative, Chinese factory jobs are also at risk: by 2016 Foxconn had replaced 60,000 production workers with robots, and was planning to replace most of the others within several years. ${ }^{2}$

For some observers, Uber's autonomous vehicles and Foxconn's robots are harbingers of a jobless future, as machines and algorithms threaten to put vast swaths of the labor force in the United States and worldwide out of work or into desperate competition for the jobs that remain. ${ }^{3}$ These

${ }^{1}$ See, e.g., Steven Greenhouse, Autonomous Vehicles Could Cost America 5 Million Jobs. What Should We Do About It?, L.A. TIMES (Sept. 22, 2016, 4:00 AM), http://www.latimes.com/opinion/op-ed/la-oe-greenhouse-driverlessjob-loss-20160922-snap-story.html [https://perma.cc/N49P-3ZE8]; Casey Newton, Uber Will Eventually Replace All Its Drivers with Self-Driving Cars, VERGE (May 28, 2014, 3:52 PM), https://www.theverge.com/2014/5/28/5758734/uber-will-eventuallyreplace-all-its-drivers-with-self-driving-cars [https://perma.cc/QN7WCBP9].

2 Jane Wakefield, Foxconn Replaces ‘60,000 Factory Workers with Robots,' BBC NEws (May 25, 2016), http://www.bbc.com/news/technology-36376966 [https://perma.cc/XQ3A-6DSG].

${ }^{3}$ See Erik Brynjolfsson \& Andrew McAfee, Race Against the Machine: How the Digital Revolution is Accelerating Innovation, Driving Productivity, and Irreversibly Transforming Employment and the Economy (2012) [hereinafter Race Against the Machine]; Erik Brynjolfsson \& Andrew McAfee, The Second Machine Age: Work, Progress, and Prosperity in a Time of Brilliant Technologies (2014) [hereinafter The Second Machine Age]; Martin Ford, Rise of the Robots: Technology and the Threat of a Jobless Future (2015); Jerry Kaplan, Humans Need Not Apply: A Guide to 
commentators describe an exponential growth of technologies that replicate an ever-wider range of human capabilities. ${ }^{4}$ Putting aside the more fantastical predictions about AI dominating or even devouring its human creators, ${ }^{5}$ the prospects for job destruction are eye-opening. Robotic and digital production of goods and services, coupled with advances in AI and machine learning, is poised to take over not only the routine or repetitive tasks that make up many human jobs, but some of the more advanced tasks as well. On one much-cited reckoning, nearly half of the jobs in the current economy are at risk. ${ }^{6}$ Although some new jobs are readily foreseeableespecially skilled jobs working with technology—no large new sectors or industries yet visible on the horizon appear likely to absorb the multitudes of human workers who might be displaced. Within this camp, predictions range from a tsunami of job loss to a more manageable rising tide.

For other observers, the real threat from automation is not the net loss of jobs but the growing polarization of the labor market. ${ }^{7}$ These observers note that automation generates large productivity gains and profits for some, while destroying many decent mid-level jobs. They predict a growing economic chasm between those who produce or own the new technology, or whose high-end skills are complemented by that technology, and most workers who are stuck competing, and driving down wages, for the jobs that remain. In this scenario, labor shortages in some skilled job categories will coexist with labor surpluses and downward wage pressure outside those categories.

Wealth and Work in the Age of Artificial Intelligence (2015); Andrew Stern \& Lee Kravitz, Raising the Floor: How a Universal Basic Income Can Renew Our Economy and Rebuild the American Dream (2016).

${ }^{4}$ See, e.g., RACE AGAinst THE MACHINE, supra note 3; FoRD, supra note 3.

${ }^{5}$ For example, there is the "grey goo" scenario, in which self-replicating nano-robots rapidly consume all organic matter on Earth. See K. ERIC DREXLER, ENGINES OF CREATION (1986).

${ }^{6}$ Carl Benedikt Frey \& Michael A. Osborne, The Future of Employment: How Susceptible Are Jobs to Computerisation? 44 (Oxford Martin Sch., Working Paper, 2013),

https://www.oxfordmartin.ox.ac.uk/downloads/academic/The_Future_ of_Employment.pdf [https://perma.cc/S6F6-ZSMP]). On competing estimates of automatability, see infra Section II.B.

${ }^{7}$ Richard B. Freeman, Who Owns the Robots Rules the World, IZA WORLD LAB. 1, 9 (2015), https://wol.iza.org/uploads/articles/5/pdfs/who-owns-the-robots-rules-theworld.pdf?v=1 [https://perma.cc/V8R9-7PRX]; see also TYLER COWEN, AVERAGE Is OvER: POWERING AMERICA BEYOND THE AgE OF THE GREAT STAGNATION (2013). Indeed, economists who do see a new threat from automation tend to predict a greater impact on wages than on employment. See Freeman, supra, at 4. 
The prospect of large net job losses and sharper income polarization has generated new interest in the old idea of a universal basic income (UBI), and a vigorous debate over its merits and plausibility. ${ }^{8}$ Other policy proposals have surfaced as well, including regulation of maximum working hours, ${ }^{9}$ and public investments in job creation and in education and training. But first we must turn to the other side in the debate over the future impact of automation on jobs.

The prediction that automation will supplant human labor on a massive scale must be taken with a large grain of salt, for it has recurred in both utopian and dystopian flavors throughout the history of industrialization without yet being realized. ${ }^{10}$ Futurists of the past have predicted that mass automation will usher in an era of human liberation from toil, or that it will immiserate all but the fortunate few who own or create the machines. ${ }^{11}$

${ }^{8}$ Among proponents, see PHILIPPE VAN PARIJS, REAL FREEDOM FOR ALL: WHAT (IF
ANYTHING) CAN JUSTIFY CAPITALISM? 150-53 (1995); STERN \& KRAVITZ, supra
note 3; Philippe Van Parijs, Basic Income: A Simple and Powerful Idea for the
Twenty-First Century, in REDESIGNING DISTRIBUTION: BASIC INCOME AND
STAKEHOLDER GRANTS AS CORNERSTONES FOR AN EGALITARIAN CAPITALISM 3, 4
(Erik Olin Wright ed., 2006); and Erik Olin Wright, Basic Income, Stakeholder
Grants, and Class Analysis, 32 POL. \& SoC’Y 79 (2004). The idea has been around
for a long time, and has advocates in unlikely places. See, e.g., MiLTON FRIEDMAN,
CAPITALISM AND FrEEDOM (1962). Indeed, the idea can be traced back to the
sixteenth century and Thomas More’s Utopia. See History of Basic Income, BASIC
InCOME EARTH NETwORK, http://basicincome.org/basic-income/history/
[https://perma.cc/B4TK-CHQK]. The UBI has attracted criticism as well. See, e.g.,
Daniel Sage \& Patrick Diamond, Europe's New Social Reality: The Case Against
Universal Basic Income, PoLICY NETwORK (Feb. 16 2017), http://www.policy-
network.net/publications/6190/Europes-New-Social-Reality-the-Case-Against-
Universal-Basic-Income [https://perma.cc/PKB9-JCRR].
${ }^{9}$ See Matthew Dimick, Better Than Basic Income? Liberty, Equality, and the Regulation of Working Time, 50 IND. L. REV. 473 (2017). Dimick argues that tighter regulation of working hours is a better solution than the UBI to various problems, including the prospect of technological unemployment. I address the proposal briefly below, see infra Section IV.B.

${ }^{10}$ See, e.g., John Maynard Keynes, Economic Possibilities for our Grandchildren (1930), reprinted in JOHN MAYNARD KEYNES, ESSAYS IN PERSUASION (1963) (predicting that the standard of life in the U.S. and Europe would improve so dramatically in one hundred years that people would work only three hours per day).

${ }^{11}$ Ryan Avent, Opinion, A World Without Work Is Coming-It Could Be Utopia or It Could Be Hell, GUARDIAN (Sept. 19, 2016, 01:00 PM), https://www.theguardian.com/commentisfree/2016/sep/19/world-without-workutopia-hell-human-labour-obsolete [https://perma.cc/4XTP-XM4Y]; Ross Douthat, Opinion, A World Without Work, N.Y. TIMES (Feb. 23, 2013), http://www.nytimes.com/2013/02/24/opinion/sunday/douthat-a-world-withoutwork.html [https://perma.cc/8ZPA-CXSQ]; Bernard Marr, The 4th Industrial Revolution and a Jobless Future-A Good Thing?, FORBES (March 3, 2017, 2:05 AM), https://www.forbes.com/sites/bernardmarr/2017/03/03/the-4th-industrial- 
Time and again, however, history has defied such predictions. Automation has been taking place for centuries, and has been a major driver of growth and prosperity. The destruction of some jobs has been offset by the creation of other jobs, usually better-paid and less grueling. ${ }^{12}$ The history of automation's impact on the labor market has been one of "creative destruction," a mantra to which many economists adhere today. For those who are confident that past trends will continue, the current wave of automation anxiety amounts to misguided scare-mongering by modern day Luddites. ${ }^{13}$

The debate over automation and jobs rages within and between the fields of economics and information technology. ${ }^{14}$ Among nearly 1900 technology experts who were canvassed in 2014, nearly half said they believed that "networked, automated, $[\mathrm{AI}]$ applications and robotic devices [will] have displaced more jobs than they have created by 2025." 15 By contrast, a survey of academic economists also from 2014 found wide agreement that "advancing automation has not historically reduced employment in the United States"16 (which of course sidesteps the claim that "this time is different"). Yet one-third of them agreed that automation

revolution-and-a-jobless-future-a-good-thing/\#476c972f44a5

[https://perma.cc/UT6T-36LV]; Derek Thompson, A World Without Work, ATLANTIC (July/Aug. 2015),

https://www.theatlantic.com/magazine/archive/2015/07/world-without-work/395294/ [https://perma.cc/M75C-H7U2].

${ }^{12}$ David H. Autor, Why Are There Still So Many Jobs? The History and Future of Workplace Automation, 29 J. ECON. PERSP. 3, 10 (2015).

${ }^{13}$ See, e.g., Ben Miller \& Robert D. Atkinson, Are Robots Taking Our Jobs, or Making Them?, INFO. TeCH. \& INNOVATION Found. 1 (Sept. 2013), https://www2.itif.org/2013-are-robots-taking-jobs.pdf [https://perma.cc/XP76QWXF].

${ }^{14}$ Empirical evidence of the impact of automation on employment to date is scarce, see Freeman, supra note 7, though one recent study by two leading economists found that investments in robots are associated with localized net job losses. Daron Acemoglu \& Pascual Restrepo, Robots and Jobs: Evidence from US Labor Markets (Mar. 17, 2017), https://economics.mit.edu/files/12763 [https://perma.cc/5A9C8FU4]. For some early reactions, see Thomas Claburn, Robots Are Killing Jobs After All, Apparently: One Droid Equals 5.6 Workers, Register (Mar. 28, 2017, 10:22 PM), https://www.theregister.co.uk/2017/03/28/robots_are_killing_jobs_after_all [https://perma.cc/UNY3-SR9N].

${ }^{15}$ Aaron Smith \& Janna Anderson, AI, Robotics, and the Future of Jobs, PEw RESEARCH CTR. 5 (Aug. 6, 2014), http://www.pewinternet.org/2014/08/06/future-ofjobs [http://perma.cc/PG4R-LHYK].

${ }^{16}$ Robots, IGM ForUM, CHICAGO BOOTH (Feb. 25, 2014, 1:55 PM), http://www.igmchicago.org/surveys/robots [http://perma.cc/QY4Y-MPUY]. 
was "a central reason why median wages have been stagnant in the US over the past decade, despite rising productivity." 17

The debate over automation also confounds ideological affinities. For example, economists at the left-leaning Economic Policy Institute reject both the job-killing story and the income-polarization story about automation. ${ }^{18}$ For them, the very real problem of wage stagnation stems not from technology but from globalization of trade and finance, declining union strength, and lagging enforcement of labor standards. By contrast, labor-friendly Harvard economist Richard Freeman believes that this time really is different, and that technology has already contributed to a historic shift in the distribution of income over the past two decades "toward robots/capital and against labor." 19 Freeman expects technology to affect wages more than employment: "The 'iron law' of the effect of robots on pay is that increased substitutability with human skills puts downward pressure on the wages of persons doing competing tasks-a pressure likely to grow in the future as technology improves the competence of robots and lowers their cost." 20

This vigorous debate is not likely to be resolved within the legal academy; yet legal scholars, and scholars of labor and employment law in particular, cannot afford to ignore it. As a society, we have used the employment relationship as a platform for delivering a plethora of rights, protections, and benefits that enable people to live a decent life. Net job losses caused by automation (among other developments) threaten to destabilize that platform. It is imperative that we try to understand how automation will affect the future law of work-and how the law of work affects the future trajectory of automation. My main objective in this Article is to attempt to frame an optimal strategy for the law of work in the face of uncertainty about the impact of automation on the labor market.

It is noteworthy that, while those who worry about workers' well-being vigorously debate the impact of automation on jobs, they are largely in

\footnotetext{
${ }^{17}$ Id.

${ }^{18}$ Lawrence Mishel \& Josh Bivens, The Zombie Robot Argument Lurches On: There Is No Evidence that Automation Leads to Joblessness or Inequality, ECON. PoL'y INST. (May 24, 2017), http://www.epi.org/publication/the-zombie-robot-argumentlurches-on-there-is-no-evidence-that-automation-leads-to-joblessness-or-inequality/ [http://perma.cc/MP8X-TMBQ]; see also John Schmitt, Heidi Shierholz \& Lawrence Mishel, Don't Blame the Robots: Assessing the Job Polarization Explanation of Growing Wage Inequality (EPI-CEPR, Working Paper Nov. 19, 2013), http://www.epi.org/publication/technology-inequality-dont-blame-the-robots/ [http://perma.cc/ZUG9-7UWB].

${ }^{19}$ Freeman, supra note 7 , at 4 .

${ }^{20}$ Id.
} 
agreement about three other labor market problems: rising income inequality; eroding labor standards at the low end of the labor market; and the causal role of "fissuring," or the growing use of outside contractors instead of employees, in both trends. If we can find ways to meet the stillcontested challenge of automation that will also address (or at least not exacerbate) the more certain challenges of fissuring, inequality, and eroding labor standards, then we will be on solid ground.

To begin, it is important to recognize that many aspects of the law of work effectively tax the employment of human labor. To that extent it is a factor both in firms' flight from direct employment through fissuring and in their substitution of machines for human workers. In response to fissuring, many scholars and advocates seek to extend firms' legal responsibility for the workers on whose labor they rely, mainly by expanding the definitions of "employee" and "employer." But automation offers firms a more complete exit from the costs, risks, and hassles associated with use of human labor. As such, extending firms' legal responsibility for independent contractors or employees not only fails to meet the challenge of automation, it also modestly exacerbates that challenge by raising the cost of human labor versus machines. As technology becomes an increasingly capable and costeffective competitor to human workers, it may doom the prevailing strategy of shoring up what I call the fortress of employment.

In response to these concerns, this Article explores ways to reduce the legal tax on employment while protecting the essential rights and entitlements of all of those who work for a living. The basic move is to separate the question of what workers' entitlements should be from the question of where their economic burdens should fall. Some worker entitlements (a term I use to encompass rights, protections, and benefits of various kinds) are inextricable from employer duties; their cost must as a practical matter, or should as a deterrence matter, be borne by employers. But for entitlements that are not necessarily linked to employment in these ways, we should consider ways beyond employment and off of employers' balance sheets to extend the entitlements, the burden of their funding, or both. $^{21}$ That move would modestly reduce firms' incentive to replace employees with contractors and human workers with machines. At the same time, however, it would extend some basic protections to those left outside the fortress of employment, and it would open the door for the pursuit of

\footnotetext{
${ }^{21}$ A kindred strategy is sketched near the end of Brishen Rogers, Employment Rights in the Platform Economy: Getting Back to Basics, 10 HARV. L. \& POL'Y REV. 479, 517-18 (2016), as an alternative to privatization of worker benefits. Rogers touts some of the same virtues of socializing employment-based benefits: promoting economic equality, reducing employer domination, and expanding access to benefits.
} 
redistribution through alternative funding mechanisms-a more-thanincidental virtue in our increasingly unequal economy.

I begin in Part I with a closer look at how many jobs are potentially at risk from automation, how managers make decisions about automation, and whether and why we should worry about the prospect of net job losses. In Part II, I explain why the challenge of automation for the future of work confounds prevailing legal and policy responses to the challenges of fissuring, declining labor standards, and inequality. Finally, Part III seeks to chart a path forward in the face of factual uncertainty and multiple objectives.

\section{I. "This Time is Different": The Next Wave of Automation and Why We Should Worry}

The history of automation is the history of economic development. Since the onset of the Industrial Revolution, machines have been replacing human labor, beginning with production of food and other basic necessities of life such as textiles and clothing, which occupied the bulk of humanity for millennia. ${ }^{22}$ Machines and the newly collectivized modes of production that they enabled vastly increased the efficiency of production, drove down the cost of basic consumer goods, and freed up human labor for new industries that catered to the evolving appetites of a more prosperous population. ${ }^{23}$ In particular, major technological innovations from the mid-1800s to the mid1900s brought vast improvements in people's lives and standards of living. ${ }^{24}$ Since the mid-twentieth century, automation has continued to destroy some jobs, to create others, to reduce misery and drudgery on and off the job, and to generate economic growth and prosperity. ${ }^{25}$

So what's not to like about automation going forward? The answer, foreshadowed above, lies in the prospect of growing inequality and net job losses. First, the economic growth and prosperity that labor-replacing technology has helped to generate, though widely shared during the middle of the twentieth century, has been sharply skewed toward the top of the

\footnotetext{
${ }^{22}$ See Robert J. Gordon, THE Rise AND FALl OF AMERICAN Growth: THE U.S. STANDARD OF LIVING SINCE THE CIVIL WAR 595 (2016) (“[R]obots [suitable for business use] are no different in principle from the introduction of machinery dating back to the textile looms and spindles of the early British industrial revolution. Most workplace technologies are introduced with the intention of substituting machines for workers.”).

${ }^{23} \mathrm{Id}$. at 62-93.

${ }^{24}$ Id. at $94-95$.

${ }^{25}$ Id. at $566-604$.
} 
income scale since the 1970s. ${ }^{26}$ Automation has likely contributed to that skewed income distribution and will exacerbate it in the future. ${ }^{27}$ Second, because emerging technologies are able to replicate or surpass a wider swath of human capabilities, there is more reason this time around to expect job destruction to outpace job creation. But debate persists not only over whether net job destruction is likely, but also over whether that would be good or bad. Less work might sound like more of a blessing than a curse to many hard-working people, now and throughout history. This Part will address both debates, not with an eye to settling them but in order to frame the analysis that follows.

\section{A. What is New About the New W ave of Automating Technologies?}

Those who predict that the impact on jobs of the coming wave of automation will defy historical patterns point to the distinctive nature of the emerging technology. Advances in both hard and soft forms of technology_robots and algorithms, for example-are replicating a much wider range of human capabilities, and weaving together those distinct capabilities more seamlessly than ever before. The very terms "artificial intelligence" (AI) and "machine learning" hint at what is new: technology is acquiring and refining cognitive and sensory capabilities that had long been thought to be uniquely human, and is outpacing humans at increasingly complex tasks.

A few arresting examples underscore the point. Consider the lip-reading prowess of a program developed by Google and Oxford University using "deep learning" technology. In 2016, the program far outperformed an expert human lip-reader, reading four times as many clips without error. ${ }^{28}$ More familiar is the fact that computers have beat human champions at the game of Jeopardy!, 29 as well as two notoriously complex board games, chess (in 1996) ${ }^{30}$ and the even more intricate Go (in 2016). ${ }^{31}$ The Go saga suggests

\footnotetext{
${ }^{26}$ See generally THOMAs PIKETTY, CAPITAL IN THE TWENTY-FIRST CENTURY (Arthur Goldhammer trans., 2014).

${ }^{27}$ See Freeman, supra note 7, at 4-5.

${ }^{28}$ A Future That Works: Automation, Employment, and Productivity, McKINSEY GLOBAL InST., 34 [hereinafter MGI, A Future That Works], https://www.mckinsey.com/ /media/McKinsey/Global\%20Themes/Digital\%20Disru ption/Harnessing\%20automation\%20for\%20a\%20future\%20that\%20works/MGI-Afuture-that-works-Executive-summary.ashx [https://perma.cc/AB53-DV7V ].

${ }^{29}$ John Markoff, Computer Wins on “Jeopardy!”: Trivial, It's Not, N.Y. TIMEs (Feb. 16, 2011), http://www.nytimes.com/2011/02/17/science/17jeopardy-watson.html [https://perma.cc/AB53-DV7V].

${ }^{30}$ See Bruce Weber, In Upset, Computer Beats Chess Champion, N.Y. TIMES (Feb. 11, 1996), https://www.nytimes.com/1996/02/11/us/in-upset-computer-beats-chesschampion.html [https://perma.cc/28SW-XY72].
} 
what is revolutionary about AI and machine learning: Google's AlphaGo program, which beat the reigning human champion in 2016, worked by analyzing a vast database of actual human games in Go. Subsequently, a new program, AlphaGo Zero, learned the game and chose its moves based solely on the rules and logic of the game itself. Just one year after AlphaGo's triumph, "AlphaGo Zero . . . trounced the older program 100 games to zero, even when it ran on just four processors, compared with the older AI's $48 . " 32$

Another example can be found in the field of translation. In July 2016, Jason Furman, then Chair of the White House Council of Economic Advisors, used translation as a prime example of humans' enduring advantages over computers: "AI today can do decent translations but cannot come close to what a human can do with his or her knowledge of both languages, social and cultural context, and sense of the author's argument, emotional states, and intentions." 33 Just four months later, however, Google launched a new version of Google Translate that exploited recent advances in machine learning, and brought a quantum leap in quality. ${ }^{34}$ Google Translate suddenly became a much closer rival to human translatorsexcept that the former is free and instantaneous.

Of course, not many jobs require lip-reading, strategic gaming, or natural language translation. But given the complex nature of these human skills, the examples illustrate how far technology has come in recent years and how fast it is advancing. The examples also suggest the potential for replacing human labor: once these systems are developed, they can be replicated and

\footnotetext{
${ }^{31}$ See Choe Sang-Hun, Google's Computer Program Beats Lee Se-dol in Go Tournament, N.Y. TIMES (Mar. 15, 2016), https://www.nytimes.com/2016/03/16/world/asia/ korea-alphago-vs-lee-sedolgo.html [https://perma.cc/FMV5-USXK].

${ }^{32}$ See Matthew Hutson, This Computer Program Can Beat Humans at Go-With No Human Instruction, SCIENCE (Oct. 16, 2017), https://www.sciencemag.org/news/2017/10/computer-program-can-beat-humans-gono-human-instruction [https://perma.cc/LCA9-M36M].

${ }^{33}$ Jason Furman, Chairman, Council of Econ. Advisors, Is This Time Different? The Opportunities and Challenges of Artificial Intelligence, Address at N.Y. Univ. 4 (July 7, 2016),

https://obamawhitehouse.archives.gov/sites/default/files/page/files/20160707_cea_ai furman.pdf [https://perma.cc/VT7V-WQ8X].

${ }^{34}$ See Sage Lazzaro, Google Is Using Artificial Intelligence to Make a Huge Change to Its Translate Tool, N.Y. OBSERVER (Mar. 6, 2017), https://observer.com/2017/03/google-translate-neural-update/ [https://perma.cc/944Z-QF6U]; Gideon Lewis-Kraus, The Great A.I. Awakening, N.Y. TIMES MAG. (Dec. 14, 2016), https://www.nytimes.com/2016/12/14/magazine/the-great-ai-awakening.html [https://perma.cc/4KR5-6EZQ].
} 
deployed innumerable times at little or no marginal cost, while human lipreaders or translators must be paid by the hour.

Thus far, none of our examples involves robots, which spark the popular imagination but might have a more limited impact on jobs than the software innovations enabled by machine learning and the capacity to process vast troves of data. Still, robots are making big inroads in manufacturing and logistics. Just around the corner are so-called "dark factories" with so few human workers that "you could switch the lights off and leave the place to the machines." 35 It is not only manufacturing jobs that are at risk from robots. The Kiva robots that automate the "picking and packing process" at some large Amazon warehouses have sped up Amazon's operations while cutting costs by about 20 percent. ${ }^{36}$ Meanwhile, their human coworkers are ambivalent. While walking the aisles was "good cardio," said one, the new system lets him get through more orders. ${ }^{37}$ "We don't socialize as much," he said, "but it's more efficient." 38

The point can be generalized. Like the Kiva robots, technology both replaces human labor in some tasks and complements human labor, or makes it more productive, in other tasks. ${ }^{39}$ The latter function is part of how automation can create jobs. Both sides of the equation have drawn empirical scrutiny and generated debate, as discussed the next two Sections.

\section{B. Estimating Automatability and the Pace of Automation of Existing Jobs}

A recent spate of studies seeks to measure the extent of "automatability" of existing jobs..$^{40}$ Estimates vary from less than ten percent to nearly half of

\footnotetext{
${ }^{35}$ Will Knight, China Is Building a Robot Army of Model Workers, MIT TECH. REV. (Apr. 26, 2016), https://www.technologyreview.com/s/601215/china-is-building-arobot-army-of-model-workers/ [https://perma.cc/8EQV-LNN7].

${ }^{36} 10$ Most Amazing Robots in the World, VeNTURE PACT (Nov. 11, 2016), https://blog.venturepact.com/10-most-amazing-robots-in-the-world/. The Kiva robot is about 16 inches tall, weighing around 320 pounds, square-shaped, yellow machine that runs on wheels. They can run at a steady $5 \mathrm{mph}$ and haul packages weighing up to 700 pounds. Kiva robots pick up shelves of products from the warehouse floor and bring them to a human employee who picks items and then packs them for shipping. While navigating, they avoid running into each other by using sensors that talk to one another. Id.

${ }^{37}$ Donna Tam, Meet Amazon's Busiest Employee_-The Kiva Robot, CNET (Nov. 30, 2014), https://www.cnet.com/news/meet-amazons-busiest-employee-the-kiva-robot/ [https://perma.cc/FSY7-N9NB].

${ }^{38}$ Id.

${ }^{39}$ For an attempt to model both dimensions of automation, see Daron Acemoglu \& Pascual Restrepo, Artificial Intelligence, Automation and Work (Nat'l Bureau of Econ. Research, Working Paper No. 24196, 2018).

${ }^{40}$ Compare, e.g., Frey \& Osborne, supra note 6, at 44 (estimating that nearly half of all jobs are at "high risk" of automation) with Melanie Arntz et al., The Risk of
} 
the jobs in the United States. ${ }^{41}$ A 2017 report by a team of researchers at the McKinsey Global Institute (MGI) analyzed what current technology can do and what humans are currently paid to do, both at a fairly granular level, to determine how much human work in today's economy is capable of being automated. The team looked at several major economies, but the focus here is on the U.S. results. The MGI study captures both the dramatic potential for job loss and the uncertainty of its time frame and extent. ${ }^{42}$

On the capabilities of current technology, the MGI researchers identified eighteen distinct human capabilities in five broad categoriessensory perception, cognitive skills, natural language processing, social and emotional skills, and physical skills—and assessed how current technology stacks up against human performance on these dimensions. ${ }^{43}$ Not surprisingly, humans beat technology at sensing others' emotional state and responding in emotionally appropriate ways (although technology is making progress). ${ }^{44}$ On the other hand, technology already outperforms most humans in many physical and cognitive skills. ${ }^{45}$ On some tasks like data processing, computers leave even the most skilled human being in the dust.

While it is clear that machines have gained ground on humans across a wide range of skills and capabilities, how much actual human work can be automated? The MGI researchers broke down human work activities into seven large categories and analyzed what percentage of the time humans spend on each of those activities is capable of being automated "by adapting currently demonstrated technology." 46 Least automatable are management and development of people ( $9 \%$ ); application of expertise to decision making, planning, and creative tasks (18\%); interacting with stakeholders like customers, suppliers, or the public (20\%); and unpredictable physical

Automation for Jobs in OECD Countries: A Comparative Analysis 4 (OECD Soc., Emp't \& Migration Working Papers No. 189, 2016), https://www.oecdilibrary.org/social-issues-migration-health/the-risk-of-automation-for-jobs-in-oecdcountries_5jlz9h56dvq7-en [https://perma.cc/ZJU7-UGUD] (estimating that nine percent of jobs in the OECD are at risk).

${ }^{41}$ See supra note 40 and accompanying text. The OECD study above criticizes Frey \& Osborne, supra note 6, for overestimating automatability by failing to disaggregate occupations; but it appears to underestimate automatability by focusing on fully automatable jobs, and discounting firms' ability (over time) to consolidate non-automatable tasks into a smaller number of human jobs.

${ }^{42}$ MGI, A Future That Works, supra note 28, at vi.

${ }^{43} \mathrm{Id}$. at 35 exhibit 3.

${ }^{44}$ Id. at 29,35 exhibit 3,72 .

${ }^{45}$ Id. at 1, 3, 10, 23-24 exhibit 1, 26, 35 exhibit 3 . The researchers conclude that machines can match or surpass several human capabilities, including "information retrieval, gross motor skills, and optimization." Id. at 10.

${ }^{46}$ Id. at 42 \& exhibit 8. 
activities (26\%). Much more automatable are collection of data $(64 \%)$; processing of data (69\%); and predictable physical activities (81\%). ${ }^{47}$

Because the mix of workers' activities varies widely by sector and by occupation, so does automatability. The MGI researchers estimate that, at one end of the spectrum, work in the accommodation and food services sector is $73 \%$ automatable; that is, $73 \%$ of the time for which humans are now paid in that sector is spent in activities that could be automated with existing technology. By comparison, work in the health care and social assistance sector is just 36\% automatable. (Readers employed in "educational services" will be happy to learn that it is the least automatable large sector at $27 \%$. $)^{48}$ At the finer level of occupations, the work of both sewing machine operators and graders of agricultural products is nearly $100 \%$ automatable, while that of psychiatrists is between 0 and $10 \%$ automatable. ${ }^{49}$ It is not just professional jobs that are relatively insulated from automation. Some low-wage jobs are hard to automate because they involve unpredictable physical tasks (janitors, landscape workers, and domestic workers, for example) or social and emotional skills (child care or elder care, for example); but pay remains low because those basic skills are far from scarce in the labor force.

Putting these data sets together, the MGI researchers estimate that $46 \%$ of all of the time for which people are now paid in the U.S. economy is spent in activities that could be automated based on currently available technology. ${ }^{50}$ And that estimate is based only on "currently demonstrated technology." It is mainly the prospect of future innovations-including technology that exists today but has not yet been adapted to perform work in today's economy-that leads some in or near the tech sector to predict massive job losses..$^{51}$

Those who are focused on the technology itself, however, may tend to overestimate the speed or extent of job destruction. Technical automatability is only the threshold factor in firms' decisions about automation. For one, it is no easy matter to disaggregate automatable tasks from those that humans still do better. As David Autor writes, "many of the tasks currently bundled into ... jobs cannot readily be unbundled ... without a substantial drop in

\footnotetext{
${ }^{47} I d$. Not all activities within a category are equally automatable. For example, the predictable physical activities involved in "accommodation and food services" are over 90 percent automatable, while those involved in "health care and social assistance” are only 50 to 60 percent automatable. Id. at 44 exhibit 9.

${ }^{48} I d$.

${ }^{49} I d$. at 5 exhibit E2, 106.

${ }^{50} \mathrm{Id}$. at 32.

${ }^{51}$ See supra note 40 and accompanying text (cataloging differing job loss estimates, one estimating that half of all jobs will be lost due to automation).
} 
quality." ${ }^{2}$ In any case, it will take time and managerial skill to reconfigure jobs and organizations. It will also require some highly skilled workers to implement and work with the new technology; and those workers will be in high demand. ${ }^{53}$ Given these challenges and uncertainties, the MGI study is circumspect about how long it is likely to take to move from technical automatability to large-scale automation, with estimates ranging from two to six decades. The process is likely to be faster for software innovations (which are easier and cheaper to implement) than for robots, faster for higher-wage but automatable jobs, and faster in higher-wage countries like the United States. ${ }^{54}$

The MGI study identifies one large and pervasive factor in managers' decisions about automation: labor costs. If an existing technology - a robot or a software solution-is capable of performing certain tasks for which a firm currently employs humans, then the firm must weigh the costs of acquiring, operating, and maintaining the technology, and of reorganizing operations accordingly, against the potential gains. ${ }^{55}$ Chief among those gains is labor cost savings: How many hours of human labor could be saved, and what are the direct and indirect costs associated with that labor? Other less-quantifiable gains in safety, reliability, and quality, for example, may be even greater in some cases. But labor costs are obviously crucial, and will inevitably affect the pace of automation. As a result, the most automatable jobs may not be the first to disappear. For example, while jobs in "accommodations and food services" are among the most automatable in the U.S. economy (73\%), low wages in that sector tend to slow the process of automation. ${ }^{56}$ I will return below to the link between labor costs and automation decisions.

The MGI report concludes that automation is currently proceeding too slowly to garner all of the gains that it could generate. ${ }^{57}$ Firms are failing to capture the efficiency gains that are already possible with existing technology, and that are necessary, especially in aging societies, to increase

\footnotetext{
${ }^{52}$ Autor, supra note 12, at 27.

${ }^{53}$ MGI, A Future That Works, supra note 28, at 114-15.

${ }^{54}$ Id. at $10,12,40,53,76-77,80,83,95-96$.

${ }^{55} \mathrm{Id}$. at $67-70$.

${ }^{56} I d$. at 7 exhibit E4, 68.

${ }^{57}$ Id. at 109-116; see also Furman, supra note 33, at 4 ("We have had substantial innovation in robotics, AI, and other areas in the last decade. But we will need a much faster pace of innovation in these areas to really move the dial on productivity growth going forward.”); Matthew Yglesias, The Automation Myth, Vox (July 27, 2015, 7:00 AM), http://www.vox.com/2015/7/27/9038829/automation-myth [http://perma.cc/Y7R6-BWTR] (arguing the pace of automation must accelerate to meet society's basic needs).
} 
productivity and drive economic growth. But even if faster automation can generate greater gains, it might also generate greater losses in the form of displaced workers. That depends on the other side of the equation-new job creation - and that is where debate about automation and jobs is least empirically grounded.

\section{New Job Creation: Labor Complementarity, Consumer Surplus, and New Kinds of Jobs (But How Many?)}

Like many economists, the MGI researchers tend toward optimism about the economic impact of technology, including their faith that historical patterns of creative destruction through innovation will continue. Their prediction that automation would spur economic growth in the United States and across the globe ${ }^{58}$ was based on an explicit assumption that "human labor displaced by automation would rejoin the workforce and be as productive as it was in 2014, that is, new demand for labor will be created." 59 That looks like a colossal leap of faith when compared with the meticulous and sophisticated analysis behind the estimates of likely job losses.

A more recent MGI report does seek to identify sources of new or increased demand for labor that might absorb workers displaced by automation, and to quantify new job creation. ${ }^{60}$ That study parallels efforts by leading economists to model the impact of automation on both job destruction and job creation and to come to grips analytically with the contingencies affecting the economy's absorption of displaced workers into new jobs. ${ }^{61}$ As Daron Acemoglu and Pascual Restrepo emphasize in a recent paper, contrary to "accounts emphasizing that technology always increases the demand for labor and benefits workers," some technological innovations might "simultaneously reduce wages and employment." 62 Economistsboth modelers and measurers-are thus interrogating the historically grounded conventional wisdom on creative destruction.

\footnotetext{
${ }^{58}$ MGI, A Future That Works, supra note 28, at 87-101.

${ }^{59} I d$. at 90 . Indeed, it is "vital that there be new demand for labor displaced by automation." Id.

${ }^{60}$ McKinsey Global Institute, Jobs Lost, Jobs Gained: Workforce Transitions in a Time of Automation, MCKINSEY \& Co. (Dec. 2017), https://www.mckinsey.com/ /media/McKinsey/Global\%20Themes/Future\%20of\%2 0Organizations/What\%20the\%20future\%20of\%20work\%20will\%20mean\%20for\%2 0jobs\%20skills\%20and\%20wages/MGI-Jobs-Lost-Jobs-Gained-Report-December-62017.ashx [https://perma.cc/F8TR-HEJS] [hereinafter MGI, Jobs Lost, Jobs Gained].

${ }^{61}$ Acemoglu \& Restrepo, supra note 39.

${ }^{62} I d$. at 11,6 .
} 
Automation can help to create new jobs in a few different ways. First, there will be new jobs for those who create, implement, maintain, and work with the new technology itself. ${ }^{63}$ Second, the productivity gains and cost savings stemming from automation can increase consumer incomes, which in turn can generate new demand for human labor both in existing job categories and in new jobs producing goods and services that do not exist in the current economy. ${ }^{64}$ Economists have estimated that by 2030, "9 percent of the US labor force could be employed in occupations that do not exist today." 65 Not surprisingly, efforts to quantify predictions of job creation are much hazier than the estimates of job losses, which turn on observable features of existing jobs and existing technology.

Haziness also stems from future contingencies affecting job creation. In particular, MGI's sanguine prognoses of economic growth and job creation depend on firms and governments making major investments in training and education, human services, infrastructure, and income support. ${ }^{66}$ The MGI researchers' bottom-line prediction for the United States is that job creation will just about keep pace with job destruction in the coming decades, but only if all of those stimulating and mitigating measures are indeed forthcoming - that is, only if their so-called "step-up scenario" takes place. ${ }^{67}$ Yet even the step-up scenario will not be enough, they predict, if job destruction through automation is at the faster end of the MGI's own estimated ranges. ${ }^{68}$

Even apart from those two big explicit "ifs," the MGI estimates seem to depend on some worrisome circularities. The lion's share of new jobs is supposed to stem from higher consumer incomes and the resulting increase in demand for goods and services that more productive machines will help

\footnotetext{
${ }^{63}$ MGI, Jobs Lost, Jobs Gained, supra note 60, at 7 (estimating that 20 to 50 million jobs related to developing and deploying new technology could be created by 2030); Acemoglu \& Restrepo, supra note 39, at 10 (describing new jobs that could be created to maintain and deploy new AI technologies in health care, design, and education).

${ }^{64}$ Regarding other possible sources of new jobs, see Acemoglu \& Restrepo, supra note 39, at 10 (discussing the possibility that "rapid automation may endogenously generate incentives for firms to introduce new labor-intensive tasks").

${ }^{65}$ MGI, Jobs Lost, Jobs Gained, supra note 60, at 70.

${ }^{66}$ For certain trends, the report does model both a "trendline scenario," in which current trends continue, and a "step-up scenario," in which both governments and firms take a variety of active measures to assist in absorbing and redeploying workers in new, needed services and projects. Id. at 6-8.

${ }^{67} I d$. at 14 (finding that "[e]nough jobs are created in the step-up scenario . . . to

offset both automation and the growth in labor force").

${ }^{68} \mathrm{Id}$.
} 
to generate. ${ }^{69}$ But what if income growth is sharply skewed toward the rich and especially toward owners of capital rather than being widely distributed through new decently paid jobs? ${ }^{70}$ Such a distribution would affect job growth because richer people spend proportionally less of their income to consume goods and services. ${ }^{71}$ And what if the new goods and services that people want could themselves be produced largely by robots or algorithms? These two hypotheticals offer two reasons to doubt whether increased consumer income will be the engine of job creation that it has been in the past. $^{72}$

If predictions of new job creation prove too optimistic for any of the reasons suggested above, or if job destruction outpaces current estimates, then many workers displaced from mid-level jobs over the next few decades may find themselves competing for jobs that are hard to automate but require no special human skills or that are not worth automating because wages are so low.

All sides in the debate over automation's impact on jobs are on the lookout for evidence in today's economy to support their position. Those who are skeptical that automation is having a major effect on jobs point out that no impact is yet reflected in some key statistics. ${ }^{73}$ Unemployment has fallen to historic lows, and employers in parts of the country are encountering labor shortages. ${ }^{74}$ Those skeptics also point to sluggish productivity growth in recent years. Stated simply: "If automation were rapidly accelerating, labor productivity and capital investment would also be surging as fewer workers and more technology did the work. But labor

\footnotetext{
${ }^{69}$ Id. at 6.

${ }^{70}$ See Freeman, supra note 7.

${ }^{71}$ See Acemoglu \& Restrepo, supra note 39, at 33 (predicting that new job creation would be slowed down and both displacement and inequality exacerbated if "the rise in real incomes resulting from automation ends up in the hands of an narrow segment of the population with much lower marginal propensity to consume than those losing incomes and their jobs"); see also Josh Zumbrun, How Rich and Poor Spend (and Earn) Their Money, WALL ST. J. (Apr. 6, 2015, 12:38 PM), https://blogs.wsj.com/economics/2015/04/06/how-the-rich-and-poor-spend-and-earntheir-money/ [http://perma.cc/EE8Y-PE38].

${ }^{72}$ Acemoglu \& Restrepo, supra note 39, at 6.

${ }^{73}$ See Furman, supra note 33 (arguing "that the economic impact of AI will [not] be very different from previous technological advances”); Autor, supra note 12, at 5-9.

${ }^{74}$ Binyamin Appelbaum, Lack of Workers, Not Work, Weighs on the Nation's

Economy, N.Y. TIMES (May 22, 2017), https://www.nytimes.com/2017/05/21/us/politics/utah-economy-jobs.html [https://perma.cc/2T8X-FK7S].
} 
productivity and capital investment have actually decelerated in the 2000s." 75 The coexistence of stagnant productivity growth and highly visible advances in automation technology is puzzling to many observers. ${ }^{76}$ It could be that workers are being diverted into less productive jobs in the protean but zerosum quest for market share, as Tyler Cowen has suggested. ${ }^{77}$ Or it could just be that the future impact of automation is still in the future (which is notoriously hard to predict). ${ }^{78}$

On the other hand, harbingers of future job losses might be seen in two well-documented trends. The first is the long-term decline in labor force participation-for young and old men, ${ }^{79}$ and, since the 1950s, for prime working-age men. ${ }^{80}$ (Women's workforce participation has obviously

${ }^{75}$ The Editorial Board, No, Robots Aren't Killing the American Dream, N.Y. TIMES (Feb. 20, 2017), https://www.nytimes.com/2017/02/20/opinion/no-robots-arentkilling-the-american-dream.html [https://perma.cc/J36Y-ZGWN]. The editorial cites data and economists from the Economic Policy Institute. See also MiSHEL \& BIVENS supra note 18 , at 10 .

${ }^{76}$ As Larry Summers put it, "Any fully-satisfactory [sic] synthetic view has to reconcile those two observations. I have not heard them satisfactorily reconciled. This is something we have to figure out.” Larry Summers, Former Dir., Nat'l Econ. Council, Remarks at the Brookings Institute's "Future of Work” Panel (Feb. 19, 2015) (partial transcript available at https://larrysummers.com/2015/02/23/thefuture-of-jobs [https://perma.cc/JN97-QS43]).

${ }^{77}$ Cowen points to the proliferation of jobs in branding and marketing: "[M]achines are not effective at persuading, at developing advertising campaigns, at branding products or corporations, or at greeting you at the door in a charming manner. ... Those activities will remain the province of human beings for a long time to come.” Tyler Cowen, In a Robot Economy, All Humans Will Be Marketers, BLOOMBERG VIEW (July 26, 2017, 1:16 PM), https://www.bloomberg.com/view/articles/2017-0726/in-a-robot-economy-all-humans-will-be-marketers [https://perma.cc/Q9G5KPJV]. Those activities do not show up in productivity statistics because they do not produce anything; they are mostly part of a "zero- or negative-sum game" in which "[e]ach business tries to pull customers away from the other brands.” Id. The question is whether those jobs can sustain a healthy economy over the longer run. Id. ${ }^{78}$ According to Yogi Berra, Niels Bohr, and an ancient Danish proverb. It's Difficult to Make Predictions, Especially About the Future, QUOTE INVESTIGATOR (Oct. 20, 2013), https://quoteinvestigator.com/2013/10/20/no-predict/ [https://perma.cc/B437B7MS].

${ }^{79}$ See GORDON, supra note 22, at 250-53.

${ }^{80}$ The Long-Term Decline in Prime-Age Male Labor Force Participation, WhitE House COUNCIL ECON. AdVISERS 7 (June 2016), https://obamawhitehouse.archives.gov/sites/default/files/page/files/20160620_cea_p primeag_male_lfp.pdf [https://perma.cc/AZ76-5E95] [hereinafter Long-Term Decline]; see also Press Release, Bureau of Labor Statistics, U.S. Dep’t of Labor, The Employment Situation-May 2017, https://www.bls.gov/news.release/archives/empsit_06022017.pdf [https://perma.cc/T7Y3-8XPJ]. 
increased over that period, though it has fallen since 2000.81) Nationwide, twelve percent of men ages twenty-five to fifty-four, and seventeen percent of those with only a high school degree or less, were out of the labor force in 2016; that compares to two percent and three percent, respectively, in 1954. ${ }^{82}$ The second trend is a long-term decline in working hours per employee across all sectors - on one recent accounting, from nearly sixty hours per week in the 1890s to just over twenty-five hours per week in 2010.83 In short, automation has a long history of enabling the production of more goods and services with fewer total hours of human labor. Those who now predict significant net job losses due to automation posit a continuation and acceleration of those trends.

\section{Should We Worry About or Welcome a Future with Much Less Work?}

If the coming wave of automation does enable greater economic output with less need for human labor, why not celebrate? Most humans throughout modern history have aspired to a life with more leisure and less toil. The demise of child labor, the advent of the forty-hour work week, and the rise of retirement are among the greatest joint achievements of organized labor and modern industrial capitalism, with automation playing a starring role.

The prospect of large net job losses from automation has its enthusiastic proponents, especially on the left, as it has in the past. ${ }^{84}$ There is little doubt that one can imagine a world with much less paid work that many people would happily embrace. Imagine, for example, a world in which everyone can meet all of their basic economic needs while working thirty hours per week and forty weeks per year, or fewer. That world would probably include a universal basic income, access to educational opportunities throughout

\footnotetext{
${ }^{81}$ See Sandra E. Black, Diane Whitmore Schanzenbach \& Audrey Breitwieser, The Recent Decline in Women's Labor Force Participation, BROOKINGS InsT. (Oct. 2017), https://www.brookings.edu/wpcontent/uploads/2017/10/es_10192017_decline_womens_labor_force_participation_ blackschanzenbach.pdf [https://perma.cc/4YTT-8M38].

${ }^{82}$ Long-Term Decline, supra note 80, at 2.

${ }^{83}$ GoRDON, supra note 22, at 259. That is across all sectors, including agriculture. The decline before World War II reflects mainly the reduced work week and the advent of vacations; after World War II it reflects partly the entry of women into the workforce and the rise of part-time jobs. Id. at 259-60.

${ }^{84}$ See, e.g., André Gorz, Farewell to the Working Class: An Essay on Post-Industrial Socialism (1982); Kathi Weeks, The Problem with Work: Feminism, Marxism, Antiwork Politics, and Postwork Imaginaries (2011); Nick Srineck \& Alex Williams, Postcapitalism and a World Without Work (2015). These writers have predecessors among nineteenth-century social thinkers. See, e.g., Edward Bellamy, Looking Backward: 2000-1887 (1887); John Adolphus Etzler, The Paradise Within the Reach of All Men, Without Labour, by Powers of Nature and Machinery (1833).
} 
one's life, and ample public goods of all kinds. It would be a far more egalitarian and less market-centric world than we have now. Indeed, it might require a radical transformation, or even the end, of capitalism as we know it. ${ }^{85}$ If that is one's ideal vision of the future, then one might look for ways to accelerate the replacement of human labor with technology while agitating for the radical social and political changes that would be required to bring about this more egalitarian distribution of income, work, and leisure. ${ }^{86}$

But others who would welcome a world of less work might still fear large-scale net job destruction in the near or medium term. They might share with the utopian proponents of faster automation an ideal vision of the future, but diverge in what they believe is possible or likely given our current politics and social arrangements. Given those existing arrangements, a large decline in the demand for human labor threatens to leave many people not with fewer hours of work (and decent pay) but with no regular paid work at all and too little income to live a decent life. If that is what a future of less work looks like, then it would be perverse to characterize it as one of greater leisure. Leisure without an adequate source of household income is just the poverty and malaise of long-term unemployment.

The economic consequences of rising unemployment-periodic and long-term-only begin with the loss of wages. More than its European counterparts, the American social model delivers many of the material requisites of a decent life-not only income, but also retirement security and insurance for health care, disability, and unemployment-mainly through employment. ${ }^{87}$ The employment relationship is also the primary locus of most protections against discrimination, retaliation against protected activities, unsafe working conditions, and excessive work hours. Outside the highly regulated employment nexus, and above a rather stingy safety net for the poor, individuals are largely left to the tender mercies of the market, armed with whatever individual bargaining power they can muster given the

\footnotetext{
${ }^{85}$ See Randall Collins, The End of Middle-Class Work: No More Escapes, in IMMANUEL WALLERSTEIN ET AL., DOES CAPITALISM HAVE A FUTURE? (2013).

${ }^{86}$ See, e.g., SRNICEK \& WILLIAMS, supra note 84 (calling for significant wage increases as a way to accelerate automation and destruction of jobs while increasing the returns to labor).

${ }^{87}$ See David Charny, The Employee Welfare State in Transition, 74 TEX. L. REV. 1601, 1601 (1996) (“[T]he United States has relied substantially less than other industrialized countries on social welfare schemes financed and administered by the state or by quasi-public entities other than employers.”); Katherine V.W. Stone, A Fatal Mismatch: Employer-Centric Benefits in a Boundaryless World, 11 LEWIS \& CLARK L. REV. 451 (2007) (arguing the employer-centered model of social insurance and welfare benefits has largely outlived its usefulness in the new "boundaryless" workplace).
} 
intersection of their skill set with changing market conditions. Automation threatens the future reach not only of the so-called "standard employment relationship" - the long-term, full-time jobs that were the foundation of American prosperity, partial though it was-but of paid work generally.

The problem with a significant loss of paid work-if that is what we are facing-is not only an economic one. Useful work is central not only to most people's identity, but to our collective social and political life. The experience of shared work fosters social interaction and social integration, solidarity and friendship, and cooperation and compromise amidst conflict. Work and workplace relationships are a far more prolific source of communal, cooperative, and collegial ties than neighborhoods or other associations; and those ties play a crucial role in maintaining the social fabric of a diverse society. ${ }^{88}$ That social fabric will become even more frayed, and our politics even more fraught, if a growing segment of the population finds itself detached from the world of work. I think that would be true even if people's basic material needs were met by something like a universal basic income.

To be sure, people like me (and probably most of my readers) who have or aspire to fulfilling and high-status jobs may be inclined to idealize work as a source of community and identity. Labor lawyers and scholars in particular tend to romanticize the experience of shared work and solidarity among coworkers. Looking ahead, we might need to recalibrate our cultural matrix of values away from what one does for a living and toward what one does with one's life, and to reconfigure our institutions to enable people to alternate among periods of education, caring for family, recreation, civic and volunteer work, and paid work. 89

All in all, if we could ensure a reasonably fair distribution of income, leisure, and work, ${ }^{90}$ then the growing ability to replace human labor with machines and technology would have a very different valence. (Indeed, the argument developed here aims in that direction.) In the meantime, however, ours is a society in which most people's income and economic security, as well as their identity, status, and experience of collective effort toward shared aims, are all heavily dependent on paid work. That makes the

\footnotetext{
${ }^{88}$ See generally CYNTHIA ESTLUND, WORKING TOGETHER: HOW WORKPLACE BONDS STRENGTHEN A DIVERSE DEMOCRACY (2003) (arguing that the hotbed of sociability and cooperation among diverse co-workers makes workplace ties crucial in a diverse democratic society).

${ }^{89}$ See WEEKS, supra note 84 (challenging the centrality of work to identify, morality, and social organization).

${ }^{90}$ As in Thomas More's original Utopia, as it happens. Cf. supra note 8.
} 
prospect of significant net job destruction through automation deeply unsettling even if it is still highly uncertain.

In between the lines of the comparatively optimistic MGI Report, one can discern the possibility of a feverishly competitive future-a high-stakes tournament in which firms with the talent, agility, and perhaps ruthlessness to exploit labor-saving technology will be among the winners, as will individuals who learn to "race with the machines." ${ }^{11}$ It is in the nature of tournaments that losers outnumber winners, and this tournament will be true to form. Firms in competitive markets will lose out if they continue to employ people to do things that machines can do more efficiently, and if they lack the human talent and organizational agility to constantly adapt to and adopt new technology. As a result, and far more importantly, people will lose out if they fail to acquire the high-end and hard-to-automate skills that will be in greatest demand, if they lack the resources and opportunities needed to acquire those skills, or if they crumple under the pressure of the tournament itself. There will be many fewer of the decent mid-level jobs that require diligent completion of mostly routine tasks, and that have sustained the broad middle of the working population for centuries.

One cannot help but blanch at how much will be demanded of the human beings who hope to come out on top of this tournament. They will need to be highly intelligent, adaptable, and entrepreneurial about their working lives, and able continually to retrain and redeploy their talents to meet the ever-changing demands of technological innovation and dynamic market conditions. That in turn will require a high level of psychological resilience and tolerance for risk and change (as well as a strong basic education that equips them to learn how to learn). Not everyone is blessed by nature and nurture with the makings of those traits, and not everyone in our egregiously unequal society has an opportunity to cultivate those traits. Moreover, there is little room in this scenario for a balanced life, one that is not dominated by the competition to get and stay ahead in an increasingly polarized labor market.

Perhaps paradoxically, many of those who can still find work in the more polarized economy that rapid automation might produce- both at the top and the bottom of the labor market—might find themselves working

\footnotetext{
${ }^{91}$ MGI, Jobs Lost, Jobs Gained, supra note 60, at 125-27. Eric Brynjolffsson maintains that humans should "race with the machines" rather than against them. Eric Brynjolffsson \& Andrew McAfee, Race Against the Machine: How the Digital Revolution is Accelerating Innovation, Driving Productivity, and Irreversibly Transforming Employment and the Economy, MIT CTR. FOR DIG. BUS. (Jan. 2012), http://ebusiness.mit.edu/research/Briefs/Brynjolfsson_McAfee_Race_Against_the_ Machine.pdf [https://perma.cc/5T95-LDSF].
} 
very long hours, albeit for diametrically opposed reasons. Those with rare skills their employers might rationally converge around long hours of work (as we already see now). By contrast, some workers who lack rare skills will scramble to work longer hours or multiple jobs at low wages just to make ends meet.

\section{E. Alternative Futures and Why the Pace of Automation Matters}

Let me sum up the foregoing account with five possible (albeit not exhaustive) futures for workers in light of the new automation's effect on jobs: ${ }^{92}$

First, there is a dystopian vision of immiseration at the bottomgrowing unemployment, or at least desperate wage-suppressing competition for the jobs that machines can't do as well or as cheaply, but that most humans can do-and a growing concentration of wealth at the top, among those who make or own the technology and those whose scarce skills are augmented by technology. Let us posit that this is a future that is worth striving to avoid. ${ }^{93}$

Second, there is the rather complacent view that probably still predominates among economists: trust in creative destruction and capitalism. History suggests that job destruction through automation, though temporarily disruptive, is likely to be offset by creation of new and better jobs that satisfy evolving, and bottomless, consumer appetites. ${ }^{94} \mathrm{I}$ would contend that, if the first dystopian vision is a plausible future, then the second vision is too complacent-even if it is also plausible. ${ }^{95}$

Third, there is the vision of the MGI's "stepped-up scenario." If firms and governments rise to the challenge of automation by investing heavily in infrastructure, training and education, income support, and social services, then job creation can keep pace with job destruction, and we can enjoy continuing growth and prosperity. Many on the left will find this supercharged version of capitalism unappealing (albeit preferable to the first

\footnotetext{
${ }^{92}$ My terminology here echoes that of Peter Frase in Four Futures: Life After Capitalism. But his futures are more starkly futuristic and (deliberately) less tethered to realism than those sketched here.

${ }^{93}$ See Peter Frase, Four Futures: Life After CAPITALism (2016) (offering a speculative portrait of what this future might entail).

${ }^{94}$ See TL Andrews, Robots Won't Take Your Job-They'll Help Make Room for Meaningful Work Instead, QUARTZ MAG., Mar. 15, 2017; Autor, supra note 12; GORDON, supra note 22.

${ }^{95}$ Even the MGI, in its “trendline scenario," finds that net job losses are likely to mount without a range of institutional responses to stimulate job growth, promote redeployment of workers, and cushion losses. See MGI, Jobs Lost, Jobs Gained, supra note 60 , at 14 .
} 
dystopian vision) for reasons sketched above. ${ }^{96}$ But it would in any case require a suite of ambitious public policy measures and expenditures to keep job losses from outstripping job creation; and even those will be inadequate if automation proceeds faster than expected.

Fourth, there is the utopian (and perhaps post-capitalist) vision of the future in which automation enables everyone to live a decent life with little or no paid work, and with a beneficent state overseeing a fair distribution of work, leisure, and income. Many readers will dismiss this vision as hopelessly unrealistic; others will recoil from the vision of a society without paid work. But even those who find this vision both attractive and within the realm of possibility should concede that it would require a radical transformation of politics and social institutions, and a raft of ameliorative policy measures to fend off the dystopian scenario. The challenge will be much greater if automation proceeds faster than expected.

Finally, there is a fifth possible future with significantly less paid work but a fairer distribution of work, income, and leisure. That scenario would require a gradual shift toward shorter workweeks, with provision for periodic paid leaves from work, decent incomes, and universal basic social entitlements. ${ }^{97}$ Here, too, the faster automation and destruction of existing jobs proceed, the harder it would be to construct this more egalitarian and human future.

\footnotetext{
${ }^{96}$ See supra Section II.D.

${ }^{97}$ This future would build on basic features of social policy in most European countries, which are grounded in a belief that it is necessary to "constrain the free market in the name of the public interest" in order to stave off war and lay the foundation of a just society. TONY JUDT, ILL FARES THE LAND 75 (2010); see also Peter Baldwin, The Politics of Social Solidarity: Class Bases of the EUROPEAN WELFARE STATE 1875-1975 (1990) (examining the social bases of the European welfare state); GøSTA ESPING-ANDERSEN: THE THREE WORLDS OF WELFARE CAPITALISM (1990) (distinguishing three major types of welfare state in advanced Western countries); TONY JUDT, POSTWAR: A HISTORY OF EUROPE SINCE 1945 (2005). Some contemporary political actors and intellectuals in the United States are currently drawing on the ideals of European Social Democracy for both moral inspiration and concrete policy ideas in their effort to construct a humane political economy and respond to challenges such as automation. See, e.g., LESSONS From EUROPE?: WhAT AMERICANS CAN LEARN FROM EUROPEAN PUBLIC POLICIES (R. Daniel Kelemen ed., 2015); LANE KenWORTHY, SOCIAL DEMOCRATIC AMERICA (2015); STEPHEN HILL, EUROPE's PROMISE: WHY THE EUROPEAN WAY IS THE BEST HoPE IN AN INSECURE Age (2010). European Social Democracy faces its own challenges, however, on political, ideological, and economic fronts. For a wideranging assessment of these challenges, see THE CRISIS OF SOCIAL DEMOCRACY IN EUROPE (Michael Keating \& David McCrone eds., 2013). The comparative perspective on the challenge of automation to the future of work is largely beyond the scope of this Article, but I plan to take it up in future work.
} 
This last vision of the future might appeal to many readers, as it does to me. Others will disagree as to what is desirable and what is achievable. (Indeed, one dimension of an attractive future, in my view, is the room it makes for divergent choices about the mix of, and tradeoffs among, labor, leisure, and income.) It seems clear, however, that avoiding dystopia and reaching one of the better futures (better, that is, for the bottom eighty or ninety percent of the population) would require major changes both in policies and in the state of our politics. That process, too, will take time, and could careen off the rails-if it hasn't already done so-if job losses and economic misery and resentments start to mount. It is imperative that citizens and political leaders begin to focus on these alternative scenarios, and avoid simply falling by default into the dystopian future (or by complacently trusting in creative destruction, which could lead to the same result if economists turn out to be wrong).

For all these reasons, and across a wide range of views about the likelihood and the desirability of a society with much less work, the pace of automation-based job destruction is a critical factor. Public policy and public spending will have to play a large role in fostering new job creation and in equipping workers for those new jobs. But the faster jobs are destroyed, the harder it will be for job creation and worker retraining to keep pace. Faster job destruction will yield more wrenching social consequences and more inhospitable conditions for a serious and sober political debate about spreading the gains and cushioning the losses from automation.

Many bodies of law are relevant to the pace of automation. ${ }^{98}$ My aim here is to understand how labor and employment law might affect the pace of automation-related job losses, and how that body of law might best respond to the challenge of automation. To that end, it is important first to situate automation among other changes in the organization of work that have lately preoccupied labor scholars, policy makers, and advocates. That is because the prevailing prescriptions for responding to those changes within labor and employment law might counterproductively speed up automationrelated job losses.

\footnotetext{
${ }^{98}$ For example, very recent work has explored the impact of the law governing intellectual property and innovation, see Camilla A. Hrdy, Technological Un/Employment (Feb. 20, 2018) (unpublished paper), https://papers.ssrn.com/sol3/papers.cfm?abstract_id=3011735 [https://perma.cc/JG8V-5N77], and tax law, see Ryan Abbott \& Bret Bogenschneider, Should Robots Pay Taxes? Tax Policy in the Age of Automation, 12 HARV. L. \& POL'Y REV. (forthcoming 2018), http://epubs.surrey.ac.uk/821099/1/Should\%20Robots\%20Pay\%20Taxes.pdf [https://perma.cc/TH4G-N4PD].
} 


\section{How Automation Alters the Landscape of Work and Confounds Efforts to Shore Up the Fortress of Employment}

The challenge that automation poses to the future of work is in many ways continuous with the more familiar and less uncertain challenges of "fissuring"- the growing proclivity of firms to outsource, offshore, or otherwise contract out their labor needs to other firms and individuals. In particular, the managerial decisions behind both fissuring and automation reflect similar causal forces, including the manifold costs associated with direct employment of human labor. But automation is also different in very basic ways that confound prevailing strategies for coping with the challenge of fissuring.

\section{A. Fissuring, and the Growth of Outsourcing, Off-shoring, and Platform-based Work}

"Fissuring" is the now-prevalent term, coined by David Weil, for the migration of many jobs away from the profitable branded corporations that reign at the top of the economy. ${ }^{99}$ Many jobs that were done in the 1950s and 1960s within those large integrated firms-especially manufacturing and low-wage service jobs like maintenance, cleaning, security, and food services- have been contracted out to outside firms. Some outside firms supply specialized services or components; others, like temporary employment agencies, supply nothing but labor; still others, like franchisees, take over all daily operations subject to standards set by the lead firm. Across the board, however, workers typically end up worse off. Instead of enjoying the relatively high wages, benefits, promotion ladders, and formal or informal job security that used to (and may still) prevail even at the bottom of lead firms' "internal labor markets," many workers are now concentrated in low-wage supplier sectors. 100

Lower wages and widespread labor standards violations among suppliers in many sectors is due in part to intense cost-based competition that sharpens the incentive to cut corners. In addition, some suppliers are, or use, or purport to use independent contractors, who are not covered by

\footnotetext{
${ }^{99}$ See generally DAVID WEIL, THE FISSURED WORKPLACE: WHY WORK BECAME SO BAD FOR SO MANY AND WHAT CAN BE DONE TO IMPROVE IT (2017) (describing the causes and effects of corporations' growing tendency to supply labor inputs through outsourcing, franchising, and contracting).

${ }^{100}$ The terms "lead firm" and "supplier" are used here as shorthand for dynamics that recur across multiple layers of the economy. A large logistics firm is a supplier for other lead firms, but it is a lead firm relative to its own suppliers. But not all lead firms are created equal. Those firms with a valuable consumer brand that commands a price premium (for example, Apple, Inc.) have both capabilities and vulnerabilities that business-to-business firms generally do not.
} 
employment laws. And many suppliers invest little or nothing in compliance and have little physical capital or public reputation at risk in case of lawbreaking or insolvency. These conditions all contribute to the decline of wages and the erosion of labor standards that has accompanied the shift of work away from branded, publicly-traded lead firms. Fissuring enables lead firms to secure lower labor costs as well as a measure of insulation from the stench of the unlawful practices that may contribute to those lower costs.

Two kinds of fissuring have drawn especially anxious attention from scholars and advocates: the off-shoring of jobs to overseas suppliers, and the splintering of jobs into "gigs" that are or purport to be outside the employment nexus. China and Uber thus both stand for larger trends in the world of work.

In seeking to reduce production costs, many firms have contracted out labor-intensive tasks to low cost producers in developing countries. As a result, China's share of global manufacturing output grew from less than three percent in 1990 to nearly twenty-five percent in 2015. ${ }^{101}$ India, with its large reservoir of English-language skills, has become the epicenter of outsourced information-based services. ${ }^{102}$ The cost savings from transnational outsourcing stem partly from lower wages and weaker regulatory institutions and trade unions in these much poorer countries, and partly from the same forces that depress labor standards among domestic suppliers-cost-based competition in a concentrated low-wage, low-profit environment. Off-shoring is one exit option that enables firms to escape collective and regulatory efforts in more advanced economies to protect workers or improve their wages or working conditions.

Uber represents another kind of fissuring and another exit option-one that shifts work outside the employment nexus by disintegrating jobs into "gigs." 103 Drivers, writers, accountants, cleaners, artists, carpenters, care workers, web designers, software programmers, fitness instructors, and therapists are among those attempting to piece together a living from a patchwork of short-term engagements, mostly as freelancers, in today's

${ }^{101}$ See Made in China?, ECONOMIST (Mar. 12, 2015), https://www.

economist.com/news/leaders/21646204-asias-dominance-manufacturing-willendure-will-make-development-harder-others-made [https://perma.cc/FAW9PQUK].

${ }^{102}$ India Tops 2016 Outsourcing Index, HINDU Bus. LINE (Jan. 12, 2016), https://www.thehindubusinessline.com/info-tech/india-tops-2016-outsourcingindex/article8097482.ece [https://perma.cc/3TE5-LBWH].

${ }^{103}$ In one sense, the "gig economy" is not that new; it is a version of industrial piecework or the old garment industry's "putting out system" for the service economy. See Matthew W. Finkin, Beclouded Work, Beclouded Workers in Historical Perspective, 37 COMP. LAB. L. \& POL'Y J. 603, 604-11 (2016). 
economy. ${ }^{104}$ Highly valuable platforms like Uber, for their part, purport to produce nothing but the software that links consumers with the services and servants they seek. Some of these platforms induce workers to bid against each other in real time. And where the work can be done remotely — as with the microtasks posted on Amazon's Mechanical Turk ${ }^{105}$ - the bidders may include poor workers in developing countries. Some platforms thus allow firms to exit both the employment relationship and the high wage labor markets.

Platform-based work is one salient aspect of the larger trend toward outsourcing of work to individual independent contractors without any of the responsibilities and burdens that attend the employment relationship. Those responsibilities and burdens, and the worker rights and entitlements that they represent, are not merely passed down to less visible, profitable, and capable employers down the line; they are vaporized.

Some freelancers prosper, and some value the greater autonomy and flexibility of independent work. 106 But for many U.S. workers and their families, the devolution of stable and decently paid jobs into insecure and undependable contingent work and gigs is a socioeconomic disaster. That is partly because of the loss of the economic security, benefits, and social insurance programs that are, whether by law, contract, or widespread practice, attached to employment, especially in large companies. The shift of work away from lead firms toward leaner and meaner supplier firms, and from long-term full-time employment toward contingent work and gigs, is

${ }^{104}$ One large recent study found that twenty to thirty percent of working-age individuals in the United States and Europe engaged in some "independent work." McKinsey Global Institute, Independent Work: Choice, Necessity, and the Gig Economy, MCKINSEY \& CO. (2016),

https://www.mckinsey.com/ /media/McKinsey/Global\%20Themes/Employment\%2 0and\%20Growth/Independent\%20work\%20Choice\%20necessity\%20and\%20the\%2 0gig\%20economy/Independent-Work-Choice-necessity-and-the-gig-economy-Fullreport.ashx [https://perma.cc/RE86-CFZ6] [hereinafter MGI, Study on Independent Work]. Of those, most said that they did so by choice, either for their primary source of income (30\%) or for supplemental income (40\%). The remainder said they did "independent work" out of necessity, either as their primary source of income (though they would prefer a "traditional job”) (14\%), or for supplemental income (16\%). Id. at ii.

105 AMAZON MECHANICAL TURK, https://www.mturk.com [https://perma.cc/NF52A9UN].

${ }^{106}$ See MGI, Study on Independent Work, supra note 104, at 7; see generally ARUN SUNDARARAJAN, THE SHARING ECONOMY: THE END OF EMPLOYMENT AND THE RISE OF CROWD-BASED CAPITALISM (2016) (detailing many facets of the sharing economy). 
shaking the foundations of the American social model that took hold in the New Deal era. ${ }^{107}$

\section{B. Three Common Causal Factors in Automation and Fissuring: Technology, Heightened Competition, and the Costs of Employing People}

Before turning to what makes automation different from fissuring, let us first take note of three common causal forces behind all of these developments: technology, more competitive-product and capital markets, and the costs of human labor.

First, technology_obviously the essence of automation-has played a crucial role in nearly every aspect of fissuring. This includes the outsourcing to lower wage countries and platform work, by enabling firms to get the labor inputs they need without directly supervising the workers who supply those inputs. ${ }^{108}$ In short, technology lowers the transaction costs associated with explicit contracting for goods and services, or of "buying" versus "making" necessary inputs. ${ }^{109}$ Technology enables lead firms to dis-integrate products and processes into component parts, to set precise standards and specifications, and to monitor closely performance and outputs of lowercost and remote outside suppliers. Technology, in the form of container ships and bar-coding, enables Walmart meticulously to track goods from a factory in Guangdong Province in China to a store in Lexington, Kentucky. ${ }^{110}$ Technology enables Apple to maintain scrupulous quality standards while tapping into the much cheaper Chinese labor market. And it enables Uber to monitor and control drivers, to connect them with customers, and to allocate revenues, including a large share for itself.

Technology is just the means, however, and not the motivation for these developments. Both fissuring and automation are driven in part by supercharged global capital markets, in which billions of dollars move across the world in microseconds, and globalized-product markets. ${ }^{111}$ Firms that

\footnotetext{
${ }^{107}$ See generally KATHERINE V.W. STONE, FROM WIDGETS TO DIGITS: EMPLOYMENT REGULATION FOR THE CHANGING WORKPLACE (2004) (describing the changes in the American workplace over time); WeIL, supra note 99 (same); Katherine V.W. Stone, The New Psychological Contract: Implications of the Changing Workplace for Labor and Employment Law, 48 UCLA L. REV. 519 (2001) (same).

${ }^{108}$ See WEIL, supra note 99, at 54-58, 60-63, 167-74 (detailing the mechanisms by which fissuring cuts costs).

${ }^{109}$ See id. at 60-63, 171-74.

${ }^{110}$ Witold Rybcyznski, Shipping News, N.Y. REV. BoOKs (Aug. 10, 2006), https://www.nybooks.com/articles/2006/08/10/shipping-news [https://perma.cc/23LB-CVU6].

${ }^{111}$ Some observers call the resulting economy "hypercapitalism.” See Marina Vujnovic, Hypercapitalism, in THE WILEY-BLACKWELL ENCYCLOPEDIA OF GLOBALIZATION (George Ritzer ed., 2012).
} 
falter in the pursuit of cheaper means of producing goods and services risk losing both investors and market share to more efficient producers. The basic underlying dynamics of price, supply, and demand are hardwired into the market economy, although national and transnational policies have fostered the growth of transnational firms, networks, and supply chains, and have eased the movement of goods, services, and capital across national boundaries. ${ }^{112}$ Technology has obviously accelerated all of those movements. But firms use technology to eliminate or outsource jobs only when it generates higher returns to capital through lower production costs or higher productivity or both.

Automation is thus part of a larger menu of options by which those who own or manage capital seek to maximize their returns. Those who supply the robots and the algorithms that replace human labor and destroy jobs are responding to demand from firms seeking more profitable ways to produce other goods and services. All of these related trends-the development of far-flung supply chains, domestic outsourcing of labor-intensive functions, franchising of food service and hospitality services, and the rise of platformbased service providers-reflect the growing ability of lead firms to secure labor inputs without directly employing people. If robots or algorithms can supply those inputs more quickly, more reliably, more cheaply, or with less risk, so it will be.

That points to a third factor driving all these developments: the effort to reduce or avoid the costs and risks of employing human beings. For many labor scholars and advocates, it is distressing to realize the extent to which that factor drives trends in the organization and automation of work. Investment banker Steven Berkenfeld made the point in vivid terms at a 2015 Department of Labor (DOL) conference on the future of work:

As I talk to companies, yes, it's about labor savings, but that's just the starting point. It's also about indirect cost savings ... . I It's about health care liabilities, lawsuits[,] and insurance and disabilities benefits. And ... people need people. There is a whole management infrastructure that needs to go on top of every person that you employ; it's a multiplier effect. ${ }^{113}$

Still more disheartening to labor advocates, managers report that "people are a pain to manage":

\footnotetext{
${ }^{112}$ For a thoughtful discussion of this phenomenon, see Dani Rodrik, The Globalization Paradox: Democracy and the Future of the World Economy (2011). ${ }^{113}$ Steven Berkenfeld, Managing Dir., Barclays Capital, Presentation at the U.S. Department of Labor Future of Work Symposium (Dec. 10, 2015) (transcript on file with author).
} 
They have to be identified and recruited, hired and trained. They want performance reviews and promotions. They take vacations; they get sick; their kids get sick; their parents get sick; they get pregnant; they get injured on the job. Sometimes they don't get along with each other. They sue for harassment. They need all kinds of insurance and benefits. They want raises and career development, and then sometimes they quit. Then you have to start it all over again. ... [People] have needs, issues, and ambitions. And perhaps most significantly from a CEO's standpoint, they do dumb things. They give bribes and kickbacks, they discriminate and harass, they expose companies to cyber-attacks, they commit acts of negligence, misconduct, and violence, and sometimes they even deliberately sabotage. They create liabilities, they damage brands and they sometimes get CEOs fired . . . .114

Berkenfeld's bottom line brought an audible gasp from the mostly laborfriendly audience at the DOL conference: "[S]ome CEOs . . . will do anything possible, they'll explore all other alternatives so as not to hire another full-time employee." 115 As he put the point more recently, CEOs these days ask, "Can I automate it? If not, can I outsource it? If not, can I give it to an independent contractor?" In other words, "[h]iring an employee is the last resort." 116

The role of labor costs in outsourcing and other forms of fissuring is well established. ${ }^{117}$ Their role in spurring automation can similarly come as no surprise. After all, a basic postulate of labor economics holds that increases in the cost of labor-whether due to market forces, legal mandates, or collective bargaining - tend to lead firms to substitute capital, including technology, for labor. ${ }^{118}$ The growing capabilities and falling cost of labor-saving technology relative to the cost of labor make the substitution of technological capital for labor ever more appealing.

Equally unsurprising is the fact that some labor costs, and thus some part of the motivation for both automation and fissuring, stem from labor

\footnotetext{
${ }^{114} \mathrm{Id}$.

${ }^{115} \mathrm{Id}$.

${ }^{116}$ Stephen McBride, How the Coming Wave of Job Automation Will Affect You and the U.S., FORBES (Feb. 23, 2017),

http://www.forbes.com/sites/oliviergarret/2017/02/23/how-the-coming-wave-of-jobautomation-will-affect-you-and-the-us/\#29bebb963fd7 [http://perma.cc/8BTE4U9S].

${ }^{117}$ See, e.g., WEIL, supra note 99.

${ }^{118}$ Richard FreEman \& JAMEs MedofF, What Do Unions Do? (1984). That

dynamic helped to drive rising productivity and prosperity, broadly shared during the middle of the twentieth century. As we have observed, experts debate whether that is now changing as automation destroys more and better jobs than it helps to create.
} 
and employment laws. ${ }^{119}$ Some laws add predictable direct costs, such as payroll taxes for workers' compensation and unemployment insurance, Social Security, and Medicare, which can add eighteen to twenty-six percent to the base salary cost. ${ }^{120}$ Minimum wage rates obviously affect direct labor costs at the bottom of the labor market. ${ }^{121}$ Overtime laws and the "pay or play" employer mandates of the Affordable Care Act (ACA) —as long as they exist-may increase direct costs much further up the wage scale. ${ }^{122}$ Labor economists generally assume that the cost of these mandates is borne by employees through lower wages - down to the point at which minimum wage laws block further wage reductions. ${ }^{123}$ If that is so, then these laws mainly add to the cost of employing low wage workers. But evidence is

${ }^{119}$ Charlotte Alexander has explored firms’ ability to restructure work to avoid the costs of legal mandates - for example, by using independent contractors or reducing employee work hours below a minimum threshold for coverage (e.g., the Affordable Care Act's employer pay-or-play obligations accrue only for employees working more than 30 hours per week). Charlotte S. Alexander, Legal Avoidance and the Restructuring of Work, in THE STRUCTURE AND STRUCTURING OF WORK IN OrganizATIONS 311 (M. Diane Burton et al. eds., 2016). Automation may be an even better legal avoidance strategy.

${ }^{120}$ For a breakdown of the non-wage direct costs of each employee, see Jose Pagliery, You Make \$70k but Cost Your Boss \$88k, CNN MONEY (Feb. 28, 2013, 9:16 AM ET), https://money.cnn.com/2013/02/28/smallbusiness/salarybenefits/index.html [https://perma.cc/RD5C-J4AH].

${ }^{121}$ On the economic impact of minimum wage levels, see infra Section II.D.

${ }^{122}$ For example, the ACA covers employers with more than fifty employees, but only with regard to employees working over thirty hours per week. Most early studies found modest effects on employers' costs and employment levels. See, e.g., Jean Abraham \& Anne Beeson Royalty, How Has the Affordable Care Act Affected Work and Wages?, LEONARD DAVIS INST. HEALTH ECON. (Jan. 19, 2017), https://ldi.upenn.edu/brief/how-has-affordable-care-act-affected-work-and-wages [https://perma.cc/L59D-BTMS]; Fredric Blavin et al., Monitoring the Impact of the Affordable Care Act on Employers, URB. InST. (Oct. 2014),

https://www.urban.org/sites/default/files/publication/33696/413273-Monitoring-theImpact-of-the-Affordable-Care-Act-on-Employers.PDF [https://perma.cc/BNB58NGP].

${ }^{123}$ See Alan B. Krueger \& Uwe E. Reinhardt, The Economics of Employer Versus Individual Mandates, 13 HeALTH AfF. 34 (1994); Lawrence H. Summers, What Can Economics Contribute to Social Policy?: Some Simple Economics of Mandated Benefits, 79 Am. Econ. ReV. 177, 180 (1989); John Olson, What Are Payroll Taxes and Who Pays Them?, TAX Found. (July 25, 2016), https://taxfoundation.org/whatare-payroll-taxes-and-who-pays-them [https://perma.cc/9F2G-CN3A]. The cost of new mandates may also fall on employers (or consumers), at least temporarily, because it is notoriously hard to actually cut wages for current workers. See TRUMAN F. BEWLEY, WHY WAGES DON'T FALL DURING A RECESSION 173-80 (1999). They are more likely to offer slower wage increases to incumbents or lower starting wages to new hires. Id. at $1,131$. 
mixed on whether the assumption holds, and whether employers-whose decisions about employment are at the heart of the matter-believe it. ${ }^{124}$

Other laws increase the cost of employing people in less predictable ways; they are a source of risk. Consider the bevy of laws prohibiting discrimination, harassment, or retaliation. Litigation under those laws entails both tangible and intangible costs, such as harm to reputation. Employees may be on both sides of litigation, as when employees or ex-employees sue over other employees' misconduct, mistakes, or misjudgments for which the employer is liable. Employees can mistakenly or maliciously trigger corporate liabilities not only under employment laws but also under environmental laws, tax and securities laws, consumer protection laws, and other laws regulating corporate conduct. Large corporate compliance departments, which cost large firms billions of dollars per year, are devoted to avoiding or managing these risks and liabilities (not to mention those risks created by deliberate managerial decisions). ${ }^{125}$

Union organizing, strikes, and other activities that are protected by federal labor law pose another sort of risk. Most private-sector employees have the right under federal labor law to form a union, engage in collective bargaining, and collectively pressure, criticize, or boycott their employer (whether or not through a union). ${ }^{126}$ The direct costs stemming from the labor laws, including the cost of violating those laws, are small; but when workers exercise their rights through collective agitation and organizing, the costs can be substantial (though only obliquely traceable to the law). Firms spend a lot of money on "union avoidance" consultants in part to avoid those costs and risks. 127

${ }^{124}$ For evidence that employers in fact bear a large share of payroll taxes, see Daniel S. Hamermesh, New Estimates of the Incidence of the Payroll Tax, 45 SOUTHERN ECON. J. 1208 (1979). On employer beliefs regarding who pays for employment taxes, see id. at 1217; Krueger \& Reinhardt, supra note 123, at 43.

${ }^{125}$ HSBC, for example, anticipated spending \$3.3 billion on regulatory and compliance actions in 2017 alone. Richard Partington, Banks Trimming Compliance Staff as \$321 Billion in Fines Abate, BLOOMBERG (Mar. 22, 2017, 8:01 PM EDT), https:/www.bloomberg.com/news/articles/2017-03-23/banks-trimming-compliancestaff-as-321-billion-in-fines-abate [https://perma.cc/S4NN-WVX7]. Interestingly, firms are finding ways to automate some compliance tasks. Id.

${ }^{126}$ See National Labor Relations Act, 29 U.S.C. § 157 (2012).

${ }^{127}$ How much they spend is unclear. See Michael Hiltzik, Labor Dept. Finally Closes a Loophole Favoring Union-Busters-After 57 Years, L.A. TIMES (Mar. 24, 2016, 4:02 AM), https://www.latimes.com/business/hiltzik/la-fi-hiltzik-union-busting20160323-snap-htmlstory.html [https://perma.cc/6UX6-DSE9]; Dave Jamieson, It's About to Get Harder for Companies to Hide Union-Busting, HufFINGTON PosT (Mar. 23, 2016, 12:01 AM EST), https://www.huffingtonpost.com/entry/unionbusting-persuader-rule_us_56f1bdcbe4b0c3ef52172770 [https://perma.cc/HK4W- 
Labor and employment laws thus account for part of the cost of employing humans. Some legal mandates could yield countervailing productivity gains through lower turnover or higher employee morale and motivation. But most of the productivity gains that might be attributable to higher wages and benefits (according to "efficiency wage" theory) depend on their being voluntary and above what either the law or the market demands; that is what helps employers recruit and retain employees who might otherwise go elsewhere, and induce reciprocal loyalty in the form of higher effort. ${ }^{128}$ That dynamic cannot be reproduced through across-theboard minimum standards.

It is hardly a revelation that employment laws add to the cost of employing humans. Nor is that a reason by itself to oppose those laws. From a societal standpoint, those laws might serve allocative efficiency by mitigating negative externalities or overcoming collective action problems; or they might serve just distributional ends or other overriding noneconomic values. ${ }^{129}$ But none of those social gains undercuts firms' private incentive to avoid or evade those laws and their costs if they can do so. And increasingly they can do so-in part through fissuring, but more completely through automation. Automation is an entirely lawful_-indeed, almost unassailableway to avoid the costs of employing people.

\section{Why Automation Is Different}

So while automation is in one sense just another tool in the toolbox of firms seeking to reduce the costs and risks associated with in-house labor, automation is also different. Rather than separating human workers from those who use and profit from their labor, automation replaces human labor

8ZJZ]; Noam Scheiber, Rule to Require Employers to Disclose Use of Anti-Union Consultants, N.Y. TiMEs (Mar. 23, 2016), https://www.nytimes.com/2016/03/24/business/economy/union-labor-regulationconsultant-relationships.html [https://perma.cc/X5WU-6QAH].

${ }^{128}$ See Lawrence F. Katz, Efficiency Wage Theories: A Partial Evaluation, 1 NBER Macroeconomics AnN. 235 (1986); Michael L. Wachter, Neoclassical Labor Economics: Its Implications for Labor and Employment Law, in RESEARCH HANDBOOK ON THE ECONOMICS OF LABOR AND EMPLOYMENT LAW 20, 28-29 (Cynthia L. Estlund \& Michael L. Wachter eds., 2012).

${ }^{129}$ See Christine Jolls, Employment Law and the Labor Market 2 (NBER Working Paper Series, Working Paper No. 13230, 2007) (arguing that, “[i]n the presence of a market failure, legal intervention through employment law may both enhance efficiency and make employees better off"); see also Alain Supiot, Law and Labour: A World Market of Norms?, NEW LEFT REVIEW, May-June 2006, at 120 (arguing that the law can and should serve noneconomic, human values; for example, claiming that "[i]t is the law's task to widen or restrict the scope of free trade, according to whether it enhances human development or robs people of their livelihoods and plunges them into poverty”). 
inputs from any source. Where automation is feasible and cost-effective, it offers the ultimate exit from the costs, risks, and hassles of employing people, including those that stem from the law of work.

Fissuring can partially but not totally insulate lead firms from the workers who perform outsourced tasks and from the blowback that may hit even faraway lead firms when those workers suffer abuse. But robots have no human rights to be violated and no bodies to be bruised or battered. Their treatment provokes no brand-scarring scandals like those that hit Apple when a dozen Foxconn workers committed suicide in 2010, or when others were injured in explosions or suffered nerve damage from the use of dangerous chemicals in the manufacture of iPhones and iPads. ${ }^{130}$ Robots do not commit suicide and they do not suffer nerve damage.

Robots also do not demand higher wages or form unions or go on strike, as humans sometimes do. It was partly the high wages and benefits that American blue-collar workers had fought for over many decades that drove much manufacturing to China. But average wages in China rose by a factor of ten from 1990 to $2015 .{ }^{131}$ That is partly because Chinese workers themselves have been demanding higher wages, and that has helped to move a government that is anxious to avoid labor conflict to raise minimum wages and other labor standards. ${ }^{132}$ Higher wages in China have pushed some

${ }^{130}$ Tania Branigan, Chinese Workers Link Sickness to N-Hexane and Apple iPhone Screens, GUARDIAN (May 7, 2010, 1:50 PM EDT), https://www.theguardian.com/world/2010/may/07/chinese-workers-sickness-hexaneapple-iphone [https://perma.cc/G8SG-9BSB]; Nick Statt, iPhone Manufacturer Foxconn Plans to Replace Almost Every Human Worker with Robots, VERGE (Dec. 30, 2016, 5:07 PM EST), http://www.theverge.com/2016/12/30/14128870/foxconnrobots-automation-apple-iphone-china-manufacturing [https://perma.cc/KH26GY53].

${ }^{131}$ See Jiaxing \& Yangon, A Tightening Grip: Rising Chinese Wages Will Only Strengthen Asia's Hold on Manufacturing, ECONOMIST (Mar. 12, 2015), http://www.economist.com/news/briefing/21646180-rising-chinese-wages-will-onlystrengthen-asias-hold-manufacturing-tightening-grip [https://perma.cc/GU6CQKN7].

${ }^{132}$ See Cynthia Estlund, A NEW DEAL FOR ChinA's Workers? (2017). Rising wages and labor standards in China (and elsewhere) reflect some profound social forces. Karl Polanyi famously argued that the spread of capitalist markets and the commodification of labor have historically tended to provoke a countermovementboth collective agitation and political mobilization-in pursuit of social protection against harsh market forces and managers. KARL POLANYI, THE GREAT TRANSFORMATION: ThE POLITICAL AND ECONOMIC ORIGINS OF OUR Time (2d ed. 2001). The countermovement to socialize markets is far from inevitable or mechanical, especially in countries without democratic political institutions. Even in authoritarian China, however, political leaders have found it necessary to respond to the spread of labor unrest by ramping up regulation and raising wages and labor 
suppliers to poorer countries with cheaper labor; but it has pushed others to automate their Chinese factories, as we have seen. ${ }^{133}$ Some manufacturing has even returned stateside, but to factories equipped with robots and 3D printers, and staffed with a relative handful of workers who are more likely to have an engineering degree than just a high school diploma. ${ }^{134}$

Even if workers demand only a decent living wage—as the "Fight for Fifteen" does in many high-cost U.S. cities - they may bolster the case for automation. Andrew Puzder, a fast-food CEO and President Trump's first nominee for Secretary of Labor, made the point in more colloquial terms: "If you're making labor more expensive, and automation less expensivethis is not rocket science." 135 The first burger-flipping robots might be expensive relative to low-wage fast food workers. But as innovation races forward, the machines get cheaper and more efficient, while labor usually does not. At some point the up-front investment will be worthwhile, if not obligatory, for firms in a competitive market.

Unlike human labor, machines tend inexorably to get both more capable and cheaper over time. ${ }^{136}$ The falling cost and expanding capabilities of robots and algorithms stem from the mysterious but much studied dynamics of innovation. In response to firms' demand for ways to lower costs and increase productivity, tech firms on the supply side race to improve the capabilities and lower the cost of the technologies that enable both fissuring and automation. ${ }^{137}$

In short, technological innovation outpaces human evolution. That oversimplifies things, of course; for example, education can broaden human capabilities. But the functional capabilities of machines are rising faster and with fewer apparent natural limits than those of humans. At the same time, humans are unable, even if they are willing, to keep pace with the falling cost of machines. The organizational innovations under the rubric of fissuring, though facilitated by technology, still run up against the upper bounds of

standards. See Eli FrIEDMAN, INSURGENCY TRAP: LABOR POLITICS IN

POSTSOCIALIST CHINA (2014).

133 Jiaxing \& Yangon, supra note 131.

${ }^{134}$ Rothfeder, supra note \#.

${ }^{135}$ Kate Taylor, Fast-Food CEO Says He's Investing in Machines Because the Government Is Making it Difficult to Afford Employees, Bus. INSIDER (Mar. 16, 2016, 5:30 PM), https://www.businessinsider.com/carls-jr-wants-open-automatedlocation-2016-3 [https://perma.cc/HT2N-44CX].

${ }^{136}$ FORD, supra note 3.

${ }^{137}$ See Hrdy, supra note 98 (questioning whether society necessarily benefits from speeding the pace of labor-saving innovations, as intellectual property protections can do). 
human performance and the lower bounds of the cost of sustaining human beings and reproducing their labor. Automation transcends both.

So automation is different from the various forms of fissuring that have drawn so much attention from labor scholars in recent years. Automation offers firms the ultimate exit from the costs and burdens of employing human labor, including those stemming from the large body of law, developed over centuries, that regulates human labor and the sometimescomplex relationships between the users and the suppliers of labor. That is unsettling. But it reflects another basic difference between automation and fissuring: automation simply obviates some of the problems that the law of work addresses. It reduces workers' exposure to occupational illness or injury, discrimination, retaliation, or excessive hours. To the extent that robots replace human workers in dangerous jobs, OSHA (or its Chinese counterpart) has no role to play, for there are no hazards to abate or regulate. So, too, with excessive work hours or discrimination.

The law of work is largely concerned with ensuring decent terms and conditions of work in whatever jobs exist. Indeed, it reflects a societal judgment about what jobs should and should not exist. But it does not seek to ensure that jobs do exist, nor to compel firms to use humans to do things that machines can do better or cheaper or both, nor to hold firms responsible for the humans whose labor they no longer need. ${ }^{138}$ Unrelated bodies of law-environmental or consumer safety regulations, for example-might be deployed in ways that deliberately or incidentally slow the destruction of jobs. Concerns about traffic safety, whether real or misplaced, might thus slow down the advent of autonomous vehicles and thus the displacement of millions of U.S workers who make their living by driving cars or trucks. ${ }^{139}$ But the law of work itself simply isn't designed to preserve jobs or to slow the pace of job destruction in the private sector.

To be sure, a "right to work" - a right to a job and a corresponding duty of government to promote full employment-has been a recurring demand from left-liberals since the New Deal, ${ }^{140}$ and finds support in international

${ }^{138}$ Apart from a bare-bones system of temporary unemployment compensation for those who are actually laid off.

${ }^{139}$ See Why Waiting for Perfect Autonomous Vehicles May Cost Lives, RAND CORP. (Nov. 7, 2017), https://www.rand.org/blog/articles/2017/11/why-waiting-for-perfectautonomous-vehicles-may-cost-lives.html .

${ }^{140}$ The "right to work" touted by organized labor (as distinct from the anti-union "right-to-work" banner that is more familiar in U.S. public discourse) has a long tradition in the United States. See, e.g., Senator Huey P. Long, Statement of the Share Our Wealth Movement (May 23, 1935), in Congressional Record, 74th Cong., 1st sess., Vol. 79, 8040-43; Dr. Martin Luther King, Jr., Showdown for Nonviolence, Look, Vol. 32, April 16, at 24 (calling for an "economic bill of rights,” which 
labor law theory and advocacy. ${ }^{141}$ But that "right," even when it has come closest to realization, is not part of the U.S. law of work as such. ${ }^{142}$

\section{How Automation Confounds Prevailing Approaches to the Regulation of Work}

That does not mean, however, that the law of work is irrelevant to the issue of automation-related job loss. To whatever extent labor and employment law adds to the cost of human labor (without boosting its productivity), it tilts firms' calculus toward labor-saving technologies. ${ }^{143}$ The effect is likely greater at the low end of the labor market, where many highly automatable jobs reside, and where minimum-wage levels prevent firms from shifting the cost of legal mandates onto employees through lower wages. Especially at the bottom of the labor market, raising the floor on wages, benefits, and working conditions through employer mandates strengthens the business case for automation of technically automatable jobs.

That surely includes large increases in the minimum wage. The impact of raising the minimum wage on employment levels is debated among economists. Twenty years ago, Daniel Shaviro observed that " $[\mathrm{m}]$ ost economists of all ideological persuasions have long agreed that [the minimum wage] is self-defeating: it destroys jobs in the low-wage sector of

\footnotetext{
"would guarantee a job to all people who want to work and are able to work.”). For more recent calls among left-liberals for a government-backed jobs guarantee, see, e.g., Sean McElwee, Colin McAuliffe and Jon Green, Why Democrats Should Embrace a Feder Jobs Guarantee, March 20, 2018, https://www.thenation.com/article/why-democrats-should-embrace-a-federal-jobsguarantee; Mark Paul, William Darity, Jr. \& Darrick Hamilton, The Federal Job Guarantee-A Policy to Achieve Permanent Full Employment, March 9, 2018, https://www.cbpp.org/research/full-employment/the-federal-job-guarantee-a-policyto-achieve-permanent-full-employment; Neera Tanden, Carmel Martin, Marc Jarsulic, Brendan Duke, Ben Olinsky, Melissa Boteach, John Halpin, Ruy Teixeira, and Rob Griffin, Toward a Marshall Plan for America: Rebuilding Our Towns, Cities, and the Middle Class, May 16, 2017, https://www.americanprogress.org/issues/economy/reports/2017/05/16/432499/towar d-marshall-plan-america.

${ }^{141}$ For an excellent collection of essays offering theoretical, comparative, and historical perspectives on the "right to work," see THE RIGHT TO WORK: LEGAL AND PhilosophicAl Perspectives (Virginia Mantouvalou, ed.) (2015). This line of inquiry is beyond the scope of this Article, though it is one that I plan to include in future work on the topic.

${ }^{142}$ See Katherine V.W. Stone, A Right to Work in the United States: Historical Antecedents and Contemporary Possibilities, in THE RIGHT TO WORK, supra note 141, at 275.

143 The McKinsey study makes that clear. MGI, A Future that Works, supra note 28, at 7, 67-70.
} 
the economy and thus hurts many of the people it is intended to help." 144 The much-debated Card and Kruger studies in the 1990s, ${ }^{145}$ and some more recent empirical studies, have challenged that consensus. ${ }^{146}$ Others discount those studies and hold to the orthodox position. ${ }^{147}$ While the debate continues with regard to moderate increases in the minimum wage, most economists would now agree that small increases do not matter much, and that large increases generally do lead to job losses, at least among the least skilled workers. ${ }^{148}$ At any point along either spectrum, however-from small to large increases in the minimum wage, or from orthodoxy to heterodoxythe growing capabilities and falling costs of automation are bound to tilt the scales to some degree toward displacement of workers.

Puzder's comment cited above ("it's not rocket science") makes the well-nigh irrefutable point that the business case for automation is stronger if direct wage costs are $\$ 15$ an hour versus $\$ 8$ an hour. Puzder was excoriated by workers' advocates for preferring robots to workers. ${ }^{149}$ But at

${ }^{144}$ Daniel Shaviro, The Minimum Wage, the Earned Income Tax Credit, and Optimal Subsidy Policy, 64 U. CHI. L. REV. 405, 406 (1997).

${ }^{145}$ See David E. Card \& Alan B. Krueger, Myth and Measurement: The NeW ECONOMICS OF THE MinimuM WAGE (1995). For a critique of the methodology of the Card \& Kruger studies, see Shaviro, supra note 144.

${ }^{146}$ See Arindrajit Dube, T. William Lester, \& Michael Reich, Minimum Wage Effects Across State Borders: Estimates Using Contiguous Counties (Inst. for Research on Labor and Emp't, IRLE Working Paper No. 157-07, 2010), https://irle.berkeley.edu/files/2010/Minimum-Wage-Effects-Across-StateBorders.pdf. For a round-up of recent studies finding no impact of (usually modest) increases in minimum wage levels on employment, see Holly Sklar, Research Shows Minimum Wage Increases Do Not Cause Job Loss, Bus. FAIR Minimum WAGE, https://www.business forafairminimumwage.org/news/00135/research-showsminimum-wage-increases-do-not-cause-job-loss.

${ }^{147}$ See David Neumark, The Effects of Minimum Wages on Employment, FSRBF ECON. LETTER (Dec. 21, 2015), https://www.frbsf.org/economic-research/ publications/economic-letter/2015/december/effects-of-minimum-wage-onemployment.

${ }^{148}$ See supra note --. For example, liberal economist Jared Bernstein, based on recent studies including Dube, Lester \& Reich, supra note 146, concludes: “I don’t think we should worry too much about the impact of moderate minimum wage increases on labor substitution. . . Large minimum wage increases, like going to \$15 in places with low wages, are another story,” and may need to be phased in slowly. See Jared Bernstein, Minimum Wages and Capital/Labor Substitution, ON THE ECON.: JARED BERNSTEIN BLOG (Aug. 17, 2015), https://jaredbernsteinblog.com/minimum-wages-and-capitallaborsubstitution.

${ }^{149}$ Michael Hiltzik, Andy Puzder, Trump’s Choice for Labor Secretary, Is a Good Spokesman for Fast-Food Restaurant Owners. For Their Employees, Not So Much, L.A. TIMES (Dec. 8, 2016, 1:40 PM), https://www.latimes.com/business/hiltzik/la-fihiltzik-puzder-labor-20161208-story.html [https://perma.cc/9P7T-JQBW]. 
the point that robots can perform as well as humans or better at a lower cost, they will be irresistible for firms in competitive markets, lest those firms lose profits, market share and investors. That is indeed "not rocket science"; it is Capitalism 101. And if we can no longer count on new job creation to offset the jobs that will be lost, those who advocate significant hikes in the minimum wage — or in any other material labor standards that raise employer costs—face a dilemma.

A similar dilemma plagues the prevailing legal responses to fissuring. Even as law-related labor costs tend to promote fissuring in all its varied forms, including the disintegration of jobs into "gigs," fissuring tends to undermine labor standards and the employment-based social model. Faced with this very big problem, labor scholars have converged on a solution with several variations: shore up the employment relationship, or what I call the "fortress of employment," by expanding lead firms' responsibility for the wages and working conditions of the workers whose labor they use. ${ }^{150}$ Hence the proliferation of scholarship and advocacy aimed at combatting misclassification of employees as independent contractors and at expanding the definition of "employment," including the scope of "joint employment," so that it is harder for lead firms to escape responsibility for complying with labor standards. Other scholars have proposed more radically reconstructing the concept of employment, ${ }^{151}$ or dismantling the distinction between employees and independent contractors, ${ }^{152}$ or creating an intermediate category between the highly regulated employment relationship and the freewheeling domain of freedom of contract. ${ }^{153}$

Nearly all of these proposals aim to expand the responsibility of firms for the people who supply their labor inputs. That is, they aim to extend to those firms some or all of the legal costs and burdens that are conventionally tied to employment, and to extend to some "self-employed" individuals the corresponding benefits and protections. The effort to expand firms'

\footnotetext{
${ }^{150}$ See WEIL, supra note 99.

${ }^{151}$ See Jeremias Prassl, The Concept of the Employer (2015).

${ }^{152}$ See Judy Fudge, Eric Tucker \& Leah Vosko, Changing Boundaries of Employment: Developing a New Platform for Labour Law, 10 CANAD. LAB. \& EMPL. L.J. 329 (2003).

${ }^{153}$ See Guy Davidov, A Purposive Approach to Labour LaW (2016); Harry W. Arthurs, The Dependent Contractor: A Study of the Legal Problems of Countervailing Power, 16 UnIV. TORONTO L.J. 89 (1965). A more recent proposal in the United States along these lines focuses on the status of "platform-based" workers such as Uber drivers. See Seth Harris \& Alan Krueger, A Proposal for Modernizing Labor Laws for Twenty-First-Century Work: The “Independent Worker," HAMILTON PROJECT (Dec. 2015),

https://www.hamiltonproject.org/assets/files/modernizing_labor_laws_for_twenty_fi rst_century_work_krueger_harris.pdf [http://perma.cc/66AB-G82M].
} 
responsibility for workers whom they do not formally employ is vehemently opposed by some in the business community, who argue that it will squelch innovation, flexibility, and, ultimately, economic growth. ${ }^{154}$ But corporations do not merely oppose these efforts; they can often evade them by rewriting contracts and reconfiguring supplier relationships to avoid employer status. ${ }^{155}$ Smart legal tests of "employment" aim to defeat that response by ignoring the formalities that are most easily manipulated by firms, and focusing on functional issues of control (however exercised), integration into the firm's operations, or genuine entrepreneurial autonomy of the worker. ${ }^{156}$ If firms have to pay a functional price to avoid employer responsibilities, more workers will remain under the legal umbrella of employment.

The exit option of automation, however, confounds this otherwise sensible strategy of stretching the scope of employment and employer responsibility. The more successful worker advocates are in holding lead firms responsible as employers for the workers who supply their labor inputs, the more those firms have an incentive to replace workers altogether through automation where that is feasible. ${ }^{157}$ In other words, if McDonalds, Inc., is held to be the employer of its franchisees' employees, or if Uber is held to be the employer of its drivers, those firms are marginally more likely to turn to burger-flipping robots or self-driving vehicles.

An analogous dilemma recurs in the ever-evolving response to firms' offshoring of operations to lower-cost, less-regulated jurisdictions. Echoing the domestic strategy of expanding the scope of employer responsibility, advocates and scholars have sought to develop transnational regulatory tools_-some of them "soft law," others with harder edges-that would declare and enforce multinational corporations" "social responsibility" for labor conditions within their supply chains. ${ }^{158}$ Progress has been halting, and firms' public commitments outstrip actual improvements on the ground. ${ }^{159}$ But we are very far from the days when big consumer brands could respond

\footnotetext{
${ }^{154}$ In the face of that opposition, the Labor Department recently revoked an Obamaera rule expanding the definition of joint employment. See Sean Higgins, Labor Department Rescinds Expanded 'Joint Employer' Rule, WASH. EXAMINER (June 7, 2017, 11:29 AM), https://www.washingtonexaminer.com/labor-department-rescindsexpanded-joint-employer-rule [http://perma.cc/57NC-PGUH].

${ }^{155}$ WEIL, supra note 99, at 31.

${ }^{156}$ See DAVIDOV, supra note 153, at --.

${ }^{157}$ Where automation is not feasible, or where it entails a significant loss in quality of services, the fortress strategy may have the desired effect of inducing lead firms either to monitor contractors' labor practices or to bring contracted-out work back into the firm.

${ }^{158}$ See Cynthia Estlund, Regoverning the Workplace: From Self-Regulation to CoRegulation (2010).

${ }^{159}$ Id. at --.
} 
to reports of labor abuses in their supply chain - for example, child labor or forced labor-by claiming they were "just the buyer."160

Automation complicates this strategy, too. The more successful global labor regulators and advocates are in holding firms politically, socially, or even legally responsible for the labor conditions of workers in their global supply chain, the more those lead firms and their suppliers have an incentive to switch to robots. Recall the rash of negative publicity about injuries to the Foxconn workers who assemble Apple's iPhones and iPads. ${ }^{161}$ For Apple, one side benefit of Foxconn's ambitious plan to replace most of its Chinese workers with robots - starting with the most dangerous jobs-is that it will neatly sidestep most future scandals of this nature.

There is a powerful logic behind the multifaceted efforts of advocates and scholars to reconnect the most profitable and capable firms with the wages and working conditions of the workers, foreign and domestic, who supply necessary labor inputs. But this sensible response to fissuring not only fails to meet the looming though uncertain challenge of automationbased job loss; it also tends further to tilt firms' calculus away from human labor and toward machines.

At the same time, the Apple-Foxconn case illustrates again the doubleedged nature of automation for workers. Automation is enabling Foxconn to eliminate some very dangerous jobs, as well as hundreds of thousands of other jobs whose grueling nature was blamed for a spate of worker suicides in 2010. ${ }^{162}$ If the displaced workers end up with better jobs at equal or better wages, this case may show innovation and creative destruction at their most virtuous. If not, it may illustrate the double-edged nature of efforts to hold lead firms responsible for upstream working conditions, at least for poor workers who lack decent alternatives. That does not mean we should abandon those efforts, but we should proceed with eyes wide open, and be on the lookout for ways to mitigate the dilemma they pose.

${ }^{160}$ See ENFORCEMENT OF TRANSNATIONAL REgULATION: ENSURING COMPLIANCE IN A GLOBAL WORLD 241 (Fabrizio Cafaggi ed., 2012) (recounting that when early anti- sweatshop activists sought to hold companies like Gap, Nike, and Wal-Mart accountable for the conditions of their suppliers' workers, Nike claimed to be "just the buyer").

${ }^{161}$ See Charles Duhigg \& David Barboza, In China, Human Costs Are Built into an iPad, N.Y. TIMES (Jan. 25, 2012), https://www.nytimes.com/2012/01/26/business/ ieconomy-apples-ipad-and-the-human-costs-for-workers-in-china.html [https://perma.cc/5KSE-RB8G].

${ }^{162}$ David Barboza, After Suicides, Scrutiny of China's Grim Factories, N.Y. TIMES (June 6, 2010), https://www.nytimes.com/2010/06/07/business/global/07suicide.html [https://perma.cc/TN7W-UFAQ]. 


\section{A Way Forward in the Face of Uncertainty}

Workers, their organizations, and their advocates have long struggled to raise labor standards, expand employee rights and benefits, and improve their enforcement. For present purposes, we may assume that those labor standards, rights, and benefits serve the interests of workers and the society as a whole; to a great extent, they represent our evolving societal conception of "decent work." But to private firms, most of those entitlements entail net labor costs or risks that are worth avoiding if possible - in effect, they tax the employment of human labor. Fissuring strategies enable firms to avoid or evade some of those costs, and legal efforts to extend the scope of direct or joint employer responsibility aim to make that more difficult. Automation sidesteps those efforts and more completely avoids the costs of human labor, including those stemming from the law. The automation option obviously becomes ever more compelling as the cost of machines falls and their capabilities rise.

All in all, it is hard to dodge the conclusion that labor costs stemming from employment laws are among the factors that lead firms to automate jobs and replace people, thus accelerating what might be an inevitable decline in the overall demand for human labor, especially in decent mid-level jobs. That is a serious concern if, as I have argued, a relatively rapid process of automation will make it much harder for individuals, institutions, and society as a whole to mount responses that mitigate the losses and spread the gains from automation. The conclusion might seem to point in a direction that would be highly dispiriting to worker advocates and many labor and employment law scholars: perhaps we should now be looking for judicious ways to unburden or deregulate the employment relationship so as to slow down, or avoid speeding up, automation-related job losses.

There are reasons to resist this "unburdening" strategy, even apart from the basic uncertainty about the future net impact of automation on employment, and I will turn to them below. But first, we must address that basic uncertainty, for it has important implications for the strategy going forward, and for whether and in what ways to "unburden" employment. This Part will frame the objectives of an optimal strategy, illustrate how the strategy would work in several contexts, and defend it against some objections.

\section{A. Framing a Strategy in the Face of Uncertainty}

As discussed in Part I, the prospect that automation will produce sizable net job losses and growing wage disparities in the next decade or two is uncertain and hotly debated, including among those who are chiefly concerned with the well-being of ordinary workers. There is disagreement as 
well over whether a net decline in the demand for labor might be a boon for most people (at least given the political will and capacity more fairly to distribute leisure, income, and the work that remains). There is much less controversy, however, about three related problems: (i) growing economic inequality and (ii) erosion of labor standards, both of which stem partly from (iii) the fissuring of work. That is, there is wider agreement both that those trends exist and that they are detrimental to workers and society. I do not intend to argue those points further here and, for example, to rehearse arguments that our economy is too unequal and that redistribution to some degree and in some form would be desirable. I will take those propositions as given.

Given the relative certainty and consensus about inequality, erosion of labor standards, and fissuring, one might conclude that we should put a priority on addressing those problems rather than the more uncertain prospect of automation-related job losses. Unfortunately, as this Article has shown, the prevailing responses within labor and employment law to the former set of problems - that is, raising minimum labor standards and mandatory benefits and expanding the reach of employer responsibility for compliance-are likely to accelerate the loss of jobs to automation and increase the risk of net job losses.

Can we avoid the opposite problem in framing a response to the uncertain threat of automation to the future of work? That is, can we mitigate the latter threat while also addressing, or at least not exacerbating, the problems of fissuring, inequality, and deteriorating labor standards? Without pretending magically to dissolve the dilemmas flagged above, I believe it is possible to devise a strategy that will make some significant progress on all these fronts. It is possible, in short, to reduce the legal tax on employment-and thus marginally reduce firms' incentive both to replace human workers with machines and to replace employees with contractorswhile improving the quality of work and of life for most workers.

It seems axiomatic that reducing the legal tax on employment, and thus reducing the cost of labor, will tend to reduce firms' incentive to outsource labor needs and to automate them. ${ }^{163}$ The challenge is to do that while maintaining or improving labor standards and mitigating inequality. The first step in meeting that challenge lies in separating the normative question of which entitlements workers should have from the question of where the

\footnotetext{
${ }^{163}$ Indeed, to the degree that law does effectively tax the employment of human labor (as opposed to being borne by employees in the form of a lower cash wage, see supra ---), it presumably distorts firms' demand for labor versus capital in the form of labor-saving technology. See Abbott \& Bogenschneider, supra note 98, at 152. Reducing that tax would thus improve economic efficiency as well as slow the loss of jobs to automation.
} 
attendant costs should fall, or how the entitlements should be financed. (I use the term "entitlements" here, despite its political baggage, to encompass all of the rights, protections, benefits, and minimum labor standards to which workers are entitled by law.) The latter question, I will argue, is more practical than normative. In some cases it makes sense to put the costs of workers' entitlements on those who employ them, or more broadly on those who use their labor. But in some cases it does not.

Separating the question of what workers' entitlements should be from the question of how they should be paid for opens up constructive possibilities on three fronts. It allows for reducing the labor-andemployment-law tax on the use of human labor; for expanding some rights and benefits to non-employed workers; and, more than incidentally, for achieving some beneficial redistribution of income in a more efficient fashion.

\section{B. Employee Entitlements that are Inextricable from Employer Mandates}

Some of the hard-won rights and protections of workers necessarily entail duties and burdens on those who employ them. ${ }^{164}$ That is true, for example, of laws regulating workplace hazards. Employers exercise actual or potential control over many aspects of workplace safety for their employees. Forcing them to abate hazards and to internalize the costs of occupational injuries and disease gives them an incentive to exercise that control to avoid those losses. The point holds as well for laws prohibiting discrimination and retaliation (against whistleblowers, for example). The employing firm causes the harms addressed by these laws - both the harms to individual employees and the social harms of discrimination and retaliation. Forcing the firm to answer for those harms deters misconduct and encourages organizational precautions.

The point is not that these laws impose no costs or tradeoffs on employers. If compliance entails a net cost to employers that they cannot pass on to workers through lower wages, they are presumably marginally more likely to replace those workers with machines. That tradeoff should be investigated and considered by advocates and policymakers in deciding whether to legislate minimum terms and conditions of employment. But some tradeoffs between the number of jobs and their quality are obviously justified. Once we as a society conclude that a decent job entails protection from hazardous conditions and from discrimination and retaliation, then

\footnotetext{
${ }^{164}$ Or, as Brishen Rogers puts it (for reasons that overlap with those offered here), "employment-related duties should be limited to those that advance goals that can only be achieved through changes to employer policies." Rogers, supra note 21, at 518.
} 
there is no way around imposing the costs of those protections on employers (perhaps to be shared, as market conditions permit, with employees and consumers).

The same can be said of laws that regulate working time. One typical, though not invariant, feature of the employment relationship is employer control over work hours and scheduling. American legislatures have been regulating working time for well over a century, albeit in the teeth of judicial resistance until the New Deal breakthrough. ${ }^{165}$ The Fair Labor Standards Act (FLSA) of 1938 established a forty-hour work week and a time-and-ahalf overtime premium for most employees. ${ }^{166}$ More recently, worker advocates have pushed for "fair scheduling" laws in response to employers' high-tech efforts to reduce staffing costs by tailoring work schedules to customer volume. ${ }^{167}$ Presumably, laws that regulate onerous "just-in-time" scheduling practices do increase the costs of employing people in some jobs to some degree-relative, that is, to a baseline of unfettered employer discretion-and do affect firms' calculus as to whether to automate those jobs. But if the entitlement to "fair scheduling" is justified (as I think it is), then so is the regulation of employers' scheduling practices. There is no way to regulate hours and scheduling, and to protect workers' ability to plan and live their lives, without regulating employers and imposing costs on them.

For the worker entitlements that necessarily or practically entail employer duties and burdens, the scope of employer responsibility should be broad enough to protect the underlying rights and entitlements, to promote compliance, and to discourage evasion through fissuring. The law should aim to minimize the ability of lead firms to evade responsibility by misclassifying workers as independent contractors, or to avoid the cost of compliance by contracting out the work. In other words, for this subset of worker rights and entitlements, efforts to extend the reach of lead firms' responsibility make eminent good sense. Indeed, some of the entitlements themselves ought to extend to independent contractors-for example, freedom from discrimination and retaliation, or protection against hazards within the control of the contracting firm.

Again, I assume that efforts to ensure "decent work" by regulating occupational hazards, discrimination and retaliation, and working hours, and

\footnotetext{
${ }^{165}$ See Frank T. de Vyver, Regulation of Wages and Hours Prior to 1938, 6 LAW \& CONTEMP. PROBS. 323 (1939).

166 29 U.S.C. § 203 (2012).

167 See Jonathan Timm, Why Fair Scheduling Could Be Labor's Next Big Fight, IN THESE TIMES (Nov. 25, 2016), http://inthesetimes.com/article/19669/why-fairscheduling-could-be-labors-next-big-fight. The technology aims to shift the cost of as much worker down-time as possible onto workers themselves.
} 
by expanding both coverage and responsibility for compliance with those laws, does generally raise the cost of human labor relative to automation. But these entitlements are or should be part of our society's definition of "decent work," and they necessarily entail corresponding duties and burdens on employers. Debates over the establishment and enforcement of minimum labor standards and non-waivable worker rights have always been about what jobs we think are worth having at all at any particular point in our economic and social development. The growing capabilities of machines might-indeed, should — draw closer attention to that trade-off. (And if there are more efficient and equally effective means of enforcing those entitlements, we should explore them.) But once we settle on what "decent work" entails and on the corresponding necessity and justifiability of imposing certain costs on employers, we should strive to make that judgment stick as broadly as possible, knowing and even intending that some jobs will be lost as automation advances.

\section{Employee Entitlements that Can and Should Be Detached from Employer Mandates}

That prescription does not apply, however, to all entitlements that are or could be attached to employment. Some employer mandates redress no harms that are either caused or preventable by the employer, and they are not intrinsically necessary to protect the underlying entitlements.

Take health insurance, for example-a big-ticket item for many U.S. employers. ${ }^{168}$ Let us posit that employees need access to affordable health care; and that most of them need help paying for it. But should the cost fall on their employers?169 Generally speaking, employers bear no causal responsibility for the health care needs of workers or their families; and there is no deterrent logic in requiring employers to bear a portion of employees' health insurance costs, as the pay-or-play mandate of the ACA tends to do. On the contrary, the ACA might counterproductively deter some employment, for employers can escape its reach by reducing employees' hours below 30 per week, the threshold for employee coverage,

\footnotetext{
${ }^{168}$ According to a 2016 survey of employers, "Annual premiums for employersponsored family health coverage reached $\$ 18,142$ this year, up 3 percent from last year, with workers on average paying \$5,277 towards the cost of their coverage.” HENRY KAISER FAMILY FOUND., 2016 EMPLOYER HEALTH BENEFITS SURVEY, http://www.kff.org/health-costs/report/2016-employer-health-benefits-survey. Not all of these costs are the product of legal mandates, of course.

${ }^{169}$ Again, employers might pass much of the cost on to consumers or back to employees through lower pay, down to the minimum wage level, or through reduced employment. The latter, which is our main concern here, becomes more likely with increased automatability of work.
} 
or by keeping the size of their workforce below 50, the threshold for employer coverage. ${ }^{170}$ But any form of employer mandate, to the extent it imposes unavoidable costs on employers, ${ }^{171}$ will tend to discourage some employment and encourage the substitution of machines (or contractors who are not covered by the mandate) for employees, assuming labor and capital are substitutable.

Some have proposed extending guaranteed health benefits to all workers, including part-time employees and independent contractors or "gig" workers, while maintaining the link to paid work. The best of those proposals provides for benefits that are portable from job to job and funded on a pro rata basis by firms on behalf of all who perform work for them. ${ }^{172}$ The result would be to extend coverage to individuals who need it, and to reduce firms' incentive to substitute part-timers or freelancers for full-time employees. That is all to the good. But as long as the mandate is tied to the use of human labor, it will still tend to tilt the users' calculus toward the exit option of automation when that is feasible.

The point here is simple, though the details are devilish. A broad entitlement to health insurance makes good normative sense; but that does not necessarily dictate putting its cost on the users of labor. To whatever extent the funding of health benefits is uncoupled from the use of human labor, we can mitigate firms' incentive to replace employees with contractors and human labor with machines. I will return below, and only briefly, to the question of how to finance health insurance if not through an employer mandate; but for now I simply note that alternative finance mechanisms

${ }^{170}$ See Alexander, supra note 119, at 318. The empirical evidence on these effects is mixed. One study estimated "an increase in low-hours, involuntary part-time employment of a half-million to a million workers in retail, accommodations, and food services.” Marcus Dillender, Carolyn J. Heinrick \& Susan Houseman, Effects of the Affordable Care Act on Part-Time Employment, Early Evidence (Upjohn Inst., Working Paper No. 16-258, 2016), https://research.upjohn.org/cgi/viewcontent.cgi?article=1276\&context =up_workingpapers. Other studies are inconclusive or show limited effects. E.g. Abraham et al., supra note 122.

${ }^{171}$ That is, to the extent that the cost cannot be passed back to employees through lower pay or on to customers through higher prices. That question is taken up below, infra ---.

${ }^{172}$ For a proposal along these lines—-though not clearly meant to be mandatory—see Common Ground for Independent Workers: Principles for Delivering a Stable and Flexible Safety Net for All Types of Work, MEDIum (Nov. 9, 2015), https://medium.com/the-wtf-economy/common-ground-for-independent-workers83f3fbcf548f ("Everyone, regardless of employment classification, should have access to the option of an affordable safety net that supports them when they're injured, sick, in need of professional growth, or when it's time to retire.”). 
might have the additional virtues of enabling a modicum of redistribution, thus mitigating economic inequality, and of increasing the policy's efficiency.

The argument here is not that we should repeal the ACA's employer mandate, which is currently a necessary component of our health care system, before replacing it with something better. The United States was long an outlier among developed countries in relying largely on voluntary employer provision of health benefits—with a backstop of Medicaid for the poor and Medicare for the elderly, and with the increasingly weak spur of collective bargaining and competition with unionized firms. The ACA made the long-overdue shift to an employer mandate (plus a now-deceased individual mandate to cover those still left out in the cold). ${ }^{173}$ Indeed, a broader mandate that covered some independent workers would be a net improvement. ${ }^{174}$ But given a serious prospect of net job losses from automation, the tax that such employer mandates impose on the use of human labor is among the reasons to take the next step from an employment-based system toward some form of universal single-payer health care model. ${ }^{175}$ Beyond that point, the extremely complex mechanics, economics, and politics of health care are outside the scope of this paper.

Consider another example: mandatory paid leave for childcare, eldercare, or other family responsibilities. Employees should be able to take a reasonable period of time off for these basic human activities without losing either their job or their income (as they can in every other OECD country ${ }^{176}$ ). But who should bear the costs of the entitlement to family leave? To answer that question, it is necessary to distinguish between the

${ }^{173}$ The ACA model took a step closer to the so-called "Bismarck Model,” found in Germany, France, and Japan, inter alia, which also relies on private insurers and mostly private providers, with funding through mandatory employer contributions. That model similarly taxes the employment of people, but the tax is smaller because insurers are non-profit and tightly regulated, and costs are lower. See T.R. REID, THE HEALING OF AMERICA: A GLOBAL QUEST FOR BETTER, CHEAPER, AND FAIRER HEALTH CARE (2009).

${ }^{174}$ See infra ---.

${ }^{175}$ Single-payer plans may use a single government provider (as in the UK's socalled "Beveridge Model”), or may use multiple and mostly private providers (as in Canada’s National Health Insurance system. REID, supra note 173, at --. The singlepayer concept is still a political long shot in the United States, though it is seemingly gaining support. Alexander Burns \& Jennifer Medina, The Single-Payer Party?

Democrats Shift Left on Health Care, N.Y. TiMEs (June 3, 2017), https://www.nytimes.com/2017/06/03/us/ democrats-universal-health-care-singlepayer-party.html?_r=0.

${ }^{176}$ Gretchen Livingston, Among 41 Nations, U.S. Is the Outlier When it Comes to Paid Parental Leave, PEW ReSEARCH CTR. (Sept. 26, 2016), https://www.pewresearch.org/ fact-tank/2016/09/26/u-s-lacks-mandated-paidparental-leave. 
entitlement to take time off without job loss and the entitlement to be paid during that time. It clearly makes sense to require the employer to grant leave for these purposes and to restore the employee's job afterward (as the Family and Medical Leave Act does). ${ }^{177}$ Only the employer can do that, and the costs are relatively modest, or even outweighed on some accounts by intangible gains from employee morale and retention. ${ }^{178}$

But what about the larger cost of paid family leave? The employer did not cause the circumstances giving rise to the leave, and can do nothing to avoid it - or nothing good, anyway. If employers had to pay the cost of family leave directly out of current revenues, some of them would inevitably discourage and penalize leave-taking or avoid hiring likely leave-takers, such as women of childbearing age. ${ }^{179}$ To avoid this problem, state-level mandatory paid leave programs in the U.S. generally use a payroll tax, which spreads the cost of paid leave across the entire workforce. ${ }^{180}$ But a payroll tax modestly raises the cost of employing everyone, and thus potentially tilts firms' calculus toward automating work where that is feasible. ${ }^{181}$

Once again, we should recall the economists' assumption that payroll taxes generally fall on employees regardless of who nominally pays them. ${ }^{182}$ On that assumption, the resulting tax is regressive-because it generally phases out at higher income levels—but not one that should spur

\footnotetext{
${ }^{177}$ FMLA

${ }^{178}$ As calculated by

${ }^{179}$ Of course, that would be illegal, but it might not be detectable, provable, or likely to trigger a lawsuit. See Samuel Issacharoff \& Elyse Rosenblum, Women and the Workplace: Accommodating the Demands of Pregnancy, 94 Colum. L. REV. 2154 (1994).
}

${ }^{180}$ That is the case in California and New Jersey, two states with paid family leave programs. A Trump Administration proposal would link funding to unemployment compensation programs, also funded by payroll taxes. Maggie Haberman, Ivanka Trump Swayed the President on Family Leave. Congress Is a Tougher Sell, N.Y. TIMES (May 21, 2017), https:/www.nytimes.com/2017/05/21/us/politics/ivankatrump-parental-leave-plan.html.

${ }^{181}$ Paid family leave might well pay off for employers in the form of employee retention and loyalty. That is presumably why some employers voluntarily offer paid family leave benefits. For those who do not, and who would be affected by a mandate, it is possible but hardly certain that the benefits of employee retention outweigh the costs of paid leave.

${ }^{182}$ See Kelly Bedard \& Maya Rossin-Slater, The Economic and Social Impacts of Paid Family Leave in California: Report for the California Employment Development Department, CAL. EMPL. DEV. DEP'T (Oct. 13, 2016), https://www.edd.ca.gov/Disability/pdf/PFL_Economic_and_Social_Impact_Study.p df [https://perma.cc/MU6V-D3AP]. 
automation. 183 But the assumption may not comport with the beliefs of employers who make decisions about automation, and in any event it runs out at the low end of the labor market. To whatever extent the burden of mandatory paid family leave does fall on employers, it is part of a cumulative tax on employment whose incentive effects might be counterproductive in an age of accelerating automation. ${ }^{184}$

To be sure, much turns on the particulars of the program. Existing paid family leave mandates in California, New Jersey, and Rhode Island, for example, are modest, providing for partial salary replacement for four to six weeks. ${ }^{185}$ At those levels, the cost appears to be quite small, wherever it falls. ${ }^{186}$ Suppose, however, that we aspired to a more generous paid family leave mandate (like those in much of Europe.) ${ }^{187}$ And suppose that we sought to extend the entitlement to paid leave to cover a larger set of family and medical exigencies, and even to allow an annual paid vacation of at least three or four weeks, along with some number of paid holidays.

If we did all those things, we would join the overwhelming majority of the world's developed countries in the worthy effort to enable employees to care for themselves and their families and have an annual respite from work, without losing their income for those periods. ${ }^{188}$ Yet this larger entitlement to paid leave-if it were funded through a payroll tax or other mandatory

\footnotetext{
${ }^{183}$ Payroll taxes in general are the most regressive large category of taxes (in Europe as well as in the U.S.). See Briefing Book, TAX POL’y CTR. (2016), http://www.taxpolicycenter.org/briefing-book/are-federal-taxes-progressive [https://perma.cc/66M8-UC2K].

${ }^{184}$ See, e.g., Harry J. Holzer, Paid Family Leave: Balancing Benefits and Costs, BROOKINGS INST. (Jan. 30, 2017), https://www.brookings.edu/blog/social-mobilitymemos/2017/01/30/paid-family-leave-balancing-benefits-and-costs [https://perma.cc/A33C-ENQ4].

${ }^{185} \mathrm{Id}$.

${ }^{186}$ Id.; Eileen Appelbaum \& Ruth Milkman, Paid Family Leave Pays Off in
} California, HARV. Bus. REV. (Jan. 19, 2011), https://hbr.org/2011/01/paid-familyleave-pays-off-in [https://perma.cc/KNU3-T945]; The Economics of Paid and Unpaid Leave, CounCIL OF ECON. ADVISORS (JUNE 2014), https://obamawhitehouse.archives.gov/sites/default/files/docs/leave_report_final.pdf [https://perma.cc/9RVB-GRWP].

${ }^{187}$ See Erin Killian, Parental Leave: The Swedes Are the Most Generous, NPR (Aug. 8, 2011 3:59 PM EST), https://www.npr.org/sections/babyproject/2011/08/09/139121410/parental-leave-theswedes-are-the-most-generous [https://perma.cc/8J87-LRRD].

${ }^{188}$ The United States is the only OECD country that has no mandatory paid vacation or personal leave, and among the few without a right to paid holidays. See Rebecca Ray \& John Schmitt, No-Vacation Nation USA - A Comparison of Leave and Holiday in OECD Countries, European Economic and Employment Policy Brief No. 3 (ISSN 1782-2165), ETUI-REHC (2007). 
employer contribution keyed to number of employees and hours of workwould put a significant tax on employment. ${ }^{189}$ While normatively justifiable, such a tax would be counterproductive. Rather than setting up productive incentives to avoid socially harmful conduct, the mandate would give firms an added incentive to offload employees and avoid those costs through fissuring or automation.

An alternative would be to shift all or part of the cost of these social benefits onto a different and more progressive tax base. The goal would be to reduce the tax on the use of human labor. This would permit a measure of redistribution from those whose wealth and income flow from capital and technological innovation toward workers. I will return below, albeit briefly, to the question of how that might best be accomplished. The point here is that some entitlements that have historically been linked to employment should be reconceived, and their funding mechanisms reconfigured, so that they do not tax and discourage the employment of human labor. Some employer mandates usefully force employers to bear the costs of, and to avoid, socially harmful conduct within their operations. But others are politically expedient off-budget ways to finance social entitlements that bear no necessary relation to employment or to work.

For historically contingent reasons, both public policy and private ordering have held major employers in the United States-more than their counterparts in Europe-heavily responsible for their employees' ability to care for their dependents and to live a decent life through retirement. ${ }^{190}$ There is nothing wrong with that approach in principle. And it might have been sustainable in the economy of the past century, dominated as it was by vertically integrated firms with strong internal labor markets and long-term employment relationships within mostly national labor and product markets. ${ }^{191}$ But in an age of shorter job tenure, proliferating contingent work arrangements, rampant fissuring, and global production networks, we need to rethink that paradigm, as Katherine Stone and others have argued for several years. ${ }^{192}$ Rapidly advancing automation capabilities amplify the point. We need better ways of delivering basic social entitlements and meeting

\footnotetext{
${ }^{189}$ This larger entitlement would be subject to all the same qualifiers as noted above, including the greater impact on low-wage jobs.

${ }^{190}$ Stone, others. Collective bargaining between unions and major employers, wartime wage controls in the 1940s, and tax laws all played pivotal roles in the "Treaty of Detroit” that created this template. See Shayna Strom \& Mark Schmitt, Protecting Workers in a Patchwork Economy, CENTURY FOUND. 2 (Apr. 7, 2016). For more on the Treaty of Detroit, see NeLson LiCHTEnstein, WALtER Reuther: THE Most DANGEROUS MAN IN DETROIT (1995).

${ }^{191}$ Stone, A Fatal Mismatch, supra note 87, at 460.

${ }^{192}$ Id. at 464 .
} 
people's material needs that are not dependent on steady full-time employment, and that do not function as a tax on the use of human labor versus machines.

It is not just the cost of entitlements but the entitlements themselves that in some cases should extend beyond employment. ${ }^{193}$ After all, not only employees but also self-employed individuals need to be able to take time off from work without losing their entire income for the duration. ${ }^{194}$ That might be ensured through a system of "social drawing rights" to support time off from paid work - whether in employment or self-employment-for education, retraining, a job search, or volunteer civic work. ${ }^{195}$ Proposals to subsidize time out of the paid workforce for such socially valuable purposes (like other proposals for mandatory paid leave) will become even more compelling if we do begin to see significant net job losses and further declines in labor force participation. If such subsidies were funded through a broad-based and progressive tax, this would also be a way of redistributing income from the winners to the not-winners in a more polarized economy, as well as meeting the various human needs that require time away from work and distributing both work and leisure in a more equitable way. It would do all those things without taxing, and thus discouraging, the use of human labor.

The basic strategy of separating the question of what workers should be entitled to from the question of how to pay for those entitlements has complicated and surprising implications for minimum wage laws. Suppose we agree, as to the first question, that all workers deserve at least a "living wage" - enough for a single individual working full-time to meet basic material needs without public assistance. ${ }^{196}$ That obviously depends on the local cost of living. But $\$ 7.25$ per hour falls far short of a living wage, not only in high-cost states and cities (many of which have raised the local minimum wage rate), but even in the poorest counties in the nation. ${ }^{197}$ In

${ }^{193}$ See Nicolas Colin \& Bruno Palier, The Next Safety Net: Social Policy for a Digital Age, Foreign AfF. (July/Aug. 2015),

https://www.foreignaffairs.com/articles/2015-06-16/next-safety-net [https://perma.cc/3DWT-62JA].

${ }^{194}$ See Julie Kashen, The Future of Work? Paid Leave for All, CENTURY FOUND. (Mar. 8, 2018), https://tcf.org/content/commentary/future-work-paid-leave/ [https://perma.cc/6N83-J6P9] (referring to New York's recent paid family leave law that permits independent contractors and self-employed individuals to opt-in). ${ }^{195}$ See SupIOT, supra note --, at 56.

${ }^{196}$ It is more debatable whether the minimum wage should enable workers to support one or more dependents - which they may or may not have.

${ }^{197}$ One of the poorest counties in the U.S. is Holmes County, Mississippi, where the living wage is calculated to be \$10.25 per hour. See Living Wage Calculation for 
short, pegging the minimum wage to the "living wage" would require large locally-targeted increases-as much as 75 percent in some cases. ${ }^{198}$ By comparison, a national minimum wage of $\$ 15$ per hour would more than double the current minimum wage, and would far exceed a "living wage," in much of the country. ${ }^{199}$

The problem is that, as economists across the political spectrum agree, those very large wage hikes would almost certainly destroy jobs and displace workers. ${ }^{200}$ The wage-destructive tendencies of large minimum wage increases are magnified as robots become ever-better and cheaper substitutes for human workers, especially in the routine tasks entailed by many low-wage jobs. Workers do need a raise, but they also need jobs (at least under current social arrangements). So even if we agree that lowincome workers need and deserve higher incomes, we should ask whether it makes sense as a pragmatic matter to require employers to supply those higher incomes in the form of a significantly higher minimum wage. Or are there other ways to put part of that money into workers' pockets?

Indeed there are. The Earned Income Tax Credit (EITC) currently subsidizes low income earners, and funds that subsidy through general revenues in the form of a "tax expenditure." Daniel Shaviro, among others, has argued that the EITC is a better way to raise poor workers' incomes and to increase the returns to work than higher minimum wages, both because the subsidy is better targeted at low-income workers and because it does not tax and reduce employment. ${ }^{201}$ Better yet, he argued, would be a "universal lump sum payment"-essentially a guaranteed basic income—or "negative

Holmes County, Mississippi, Living WAGe CALCUlator (2018), https://livingwage.mit.edu/counties/28051 [https://perma.cc/M3EV-VTQU]. ${ }_{198}$ This would apply to Atlanta, Georgia, for example. See Living Wage Calculation for Atlanta-Sandy Springs-Roswell, GA, Living WAGE CALCUlATOR (2018), https://livingwage.mit.edu/metros/12060 [https://perma.cc/KJ7F-Y2BD].

${ }^{199}$ That is, it would double the minimum wage in all states and cities where the national minimum wage currently prevails. A minimum wage of \$15 is higher than the "living wage" for a single individual almost everywhere, though not, for example, in Manhattan (New York County, NY). See Living Wage Calculation for New York County, NY, Living WAGE CALCULATOR (2018), https://livingwage.mit.edu/counties/36061 [https://perma.cc/GUH7-2X5M].

${ }^{201}$ Shaviro, supra note 144. Notably, the EITC covers "self-employed” workers who work as independent contractors. 26 U.S.C. § 32(c)(2)(A)(ii) (2012). The EITC does not now, but could, reflect local differences in the cost of living. David Callahan, Why Not Peg EITC Benefits to the Local Cost of Living?, DEMOS (Mar. 9, 2014), https://www.demos.org/blog/3/19/14/why-not-peg-eitc-benefits-local-cost-living [https://perma.cc/manage/create?folder=4028]. 
marginal tax rates" at low income levels. ${ }^{202}$ Others have argued for "wage subsidies" that low-wage workers receive with each paycheck instead of at the end of the tax year, and without the filing requirements that keep many eligible workers from claiming the EITC. ${ }^{203}$ In one way or another, all of these alternative strategies effectively separate the question of what workers need or deserve by way of income from the question of what their employers should be required to pay them. In addition, most of them allow for, and are not incompatible with, the pursuit of legitimate redistributive aims without a counterproductive impact on employment.

This argument flies in the face of what might seem a perfectly sensible premise, and a blanket rejoinder to the whole concept of unburdening employment. Employers deserve to pay whatever workers rightly deserve to earn as a return on their labor. As the Supreme Court pointed out over 80 years ago when it finally upheld legislatures' power to set minimum wages,

[T] he denial of a living wage . . casts a direct burden for [workers'] support upon the community. What these workers lose in wages the taxpayers are called upon to pay. The bare cost of living must be met. . . . The community is not bound to provide what is in effect a subsidy for unconscionable employers. ${ }^{204}$

I find that claim normatively appealing, and certainly sufficient to uphold the constitutionality of minimum wages. Moreover, in an era of rapid industrialization, mandating higher wages helped to push firms toward more efficient (and automated) modes of production and the better jobs they created. Many would make the same claim today: If higher labor standards accelerate the destruction of low-paid jobs, so much the better, for as in the past we can expect those jobs to be replaced by better jobs.

I have offered my response above. It is at least plausible to think that this time is different, and that we face significant net job losses that will require major social and political adjustments that we can more plausibly make with a slower pace of automation. In short, to the extent that firms are increasingly able to boost profits by shedding workers and automating work, their chronic complaints about costs the labor and employment law impose

\footnotetext{
${ }^{202}$ Shaviro, supra note 144 , at 410.

${ }^{203}$ For an empirical assessment of some relatively narrow wage subsidy programs, see Lawrence F. Katz, Wage Subsidies for the Disadvantaged, (Nat'l Bureau of Econ. Research, Working Paper No. 5679, 1996). For a more polemical endorsement from a business-friendly think tank, see The Case for a Targeted Living Wage Subsidy, EMP. POLICIES INST. (2001), https://www.epionline.org/wpcontent/studies/epi_livingwage_07-2001.pdf [https://perma.cc/manage/create?folder=4028].

${ }^{204}$ West Coast Hotel v. Parrish, 300 U.S. 379, 399 (1937).
} 
on employment will have to be taken more seriously. But that need not entail cutting back on workers' entitlements; in some cases we can and should instead shift the burden of paying for those entitlements away from the employment nexus.

\section{Paying for Entitlements that Are Detached from Employment}

Thus far I have argued for expanding some entitlements and their costs, and for abandoning the current mechanism for financing them. But that raises the obvious question, already touched on, of how to pay for those entitlements. Without wandering too far into the sphere of tax policy and public finance, let us take up that question briefly.

The aim is to shift costs away from those who hire workers toward those who are leading, and profiting extravagantly from, the substitution of technology for human labor. Automation has already contributed to the troubling growth of economic inequality by increasing the returns to capital versus labor, and is likely to continue to do so going forward. ${ }^{205}$ It is increasingly both a moral and a political imperative to find ways to redistribute income from the winners in our highly polarized economy to those who have lost ground or are just scraping by. (On the political question of how to persuade more voters of the need for redistribution I will be even more brief here.)

Redistribution can be achieved, and inequality countered, through policy decisions on both the taxing side and the spending side of the public ledger. ${ }^{206}$ In the more egalitarian European countries, redistribution is accomplished less through a highly progressive tax structure than through larger public expenditures on behalf of those in need (and higher taxes overall). On the spending side, I have already argued for replacing employee entitlements with broader or universal benefits such as affordable health care, reasonably generous paid family and medical leave and vacations, decent retirement income, and income support for poor workers. But the net redistributive impact of these programs, and the impact on economic inequality, would depend on how they are financed—on the taxation side of the ledger.

It is worth noting at the outset that the payroll tax, which now finances several major employee entitlements, is perhaps the single most regressive

\footnotetext{
205 This problem is exacerbated by the U.S. tax code, which "subsidizes capital relative to labor.” See Acemoglu \& Restrepo, supra note 39, at 14; see also Abbott \& Bogenschneider, supra note 98, at 150.

${ }^{206}$ Edward D. Kleinbard, We Are Better Than This: How Government Should Spend Our Money, at xxi (2015).
} 
major source of tax revenues in the United States (and elsewhere). ${ }^{207}$ So shifting all or part of the cost of some worker entitlements from employers' payrolls to a broader and more progressive tax base would (modestly) mitigate both the incentive to automate and the growth of income inequality.

Given the multiple goals here-funding social benefits, achieving redistribution, and mitigating the incentive to automate-it seems hard to resist the idea of a "robot tax," proposed famously by Bill Gates and Elon Musk. ${ }^{208}$ On the face of it, such a tax could simultaneously slow down the replacement of people by robots, replace lost payroll tax revenues as payrolls shrink, and promote equitable redistribution from those who make and own the robots to those whose jobs they are destroying or degrading. In terms of the impact on firms' decisions about deployment of human labor versus robots, a robot tax might look like a mirror image of my proposal to reduce the law's tax on human labor (but without the attack on cherished and hardfought labor gains). Presumably, like the tax on human labor, a robot tax would affect firms' decisions only at the margin; size matters. But the basic concept might seem irresistible given all I have argued here.

Most economists scoff at the idea of a "robot tax," however. There is the daunting challenge of identifying a "robot"- they do not all look like C$3 \mathrm{PO}$ or R2-D2 in Star Wars ${ }^{209}$ - and the many non-robotic forms of automation that a robot tax would miss. More importantly, however, they say that it would drive efficiency- and productivity-enhancing capital investments from the taxing nation elsewhere, perhaps resulting in an increase in offshoring of jobs (unless it were implemented globally). ${ }^{210}$ Whether that argument reflects assumptions about the overall net societal benefits of automation, and whether it bears weight once we relax those

${ }^{207}$ That is based on the standard assumption that the payroll tax falls largely on workers themselves, and on the fact that the tax drops out at high income levels. (As of 2018, only the first $\$ 125,400$ of income is subject to the tax. Maximum Taxable Earnings (1937-2018), SOC. SECURITY ADMIN., https://www.ssa.gov/planners/maxtax.html, [https://perma.cc/manage/create?folder=4028].) If we relax the first assumption, the payroll tax would be less regressive but more likely to discourage employment.

${ }^{208}$ See The Robot that Takes Your Job Should Pay Taxes, Says Bill Gates, QUARTZ (Feb. 17, 2017), https://qz.com/911968/bill-gates-the-robot-that-takes-your-jobshould-pay-taxes [https://perma.cc/manage/create?folder=4028]; see also Abbott \& Bogenschneider, supra note 98.

${ }^{209}$ For that reason, others have proposed proxies for a "robot tax," such as a tax based on the ratio of profits to number of employees. That would avoid the problem of identifying robots, but it would exacerbate the problem of discouraging or driving away productivity-enhancing investments. 210 
assumptions, are questions I will not attempt to untangle here. ${ }^{211}$ So let me bracket the concept of a "robot tax" to consider some alternatives.

Perhaps the simplest way in the United States to achieve some redistribution of income and to pay for what are now employee entitlements is to increase the income tax and steepen its progressivity. ${ }^{212}$ We have already noted the virtues of a negative income tax over minimum wages as a way to increase incomes of poor workers; we could couple such a tax with significantly higher marginal tax rates for the richest individuals. One need not delve into the numbers to recognize that there is some income tax rate structure that could fully fund a set of universal social entitlements that would more than replace the existing system of mandatory employee benefits (as well as large increases in the minimum wage).

There are alternatives, of course, such as a wealth tax (a global version of which was proposed by Thomas Picketty as an antidote to rising inequality), ${ }^{213}$ or a European-style consumption tax (whose tendency toward regressivity could be offset either by other taxes or, on the spending side, by using increased revenues to fund redistributive programs), or some combination of taxes on income, wealth, financial transactions, and consumption. Each of these forms of taxation has its advantages and disadvantages, though this is not the place to explore those issues.

\section{E. The Broader Case for Reconstructing the Platform for Social Rights and Benefits}

This Article's argument in some ways recalls prior efforts to deal with the disintegration of the standard employment relationship and the rise of various forms of contingent work and "self-employment." 214 Those challenges, too, prompted a reconsideration of the continued viability of the contract of employment as what Brian Langille called "the 'platform' for delivering rights and benefits" as well as for imposing obligations. ${ }^{215} \mathrm{It}$

\footnotetext{
${ }^{211}$ I will note that countering the employment law tax on human labor with a tax on robots would seem to be a convoluted means of rebalancing the playing field, if that is what we are trying to do. But a robot tax might have other virtues.

${ }^{212}$ Greater progressivity could be achieved in part by eliminating some highly regressive tax expenditures including "around $\$ 100$ billion of outright subsidies every year to various business interests - subsidies that never would pass muster as cash outlays.” KLEINBARD, supra note 206, at 242.

${ }^{213}$ See PIKETTY, supra note 26, at --.

${ }^{214}$ See, e.g., ALAIN SUPIOT, BEYOND EMPLOYMENT: CHANGES IN WORK AND THE FUTURE OF LABOUR LAW IN EUROPE 56 (2001). This work was originally published as the 1999 "Supiot Report" to the European Commission, originally titled Beyond Employment, and was a landmark in that body of scholarship.

${ }^{215}$ Fudge, Tucker \& Vosko, supra note 152, at 331-32 (quoting Brian Langille, Labour Policy in Canada-New Platform, New Paradigm, 28 CANADIAN PUB. POL'y $133(2002))$.
} 
remains an important and unfinished project to consider which employee rights and benefits should be extended to others who perform work outside the employment contract. My point here, however, is that expanding "the 'platform' for delivering rights and benefits" to include self-employed workers, and expanding the responsibilities of firms accordingly, may not go far enough in an era of accelerating automation and decreasing reliance on human labor.

For much of the twentieth century, many of the entitlements of employees, workers, and citizens were bundled together in a concept that an eminent Canadian labor law scholar, Harry Arthurs, called "industrial citizenship." Industrial citizenship is "an employment-related system of entitlements which would protect workers against arbitrary treatment by their employer and the vicissitudes of the economy, old age and illness." 216 Much as the erosion of the standard employment relationship through fissuring highlighted the need to extend those entitlements beyond employment, so too the growing capabilities and falling costs of automation now highlight the need to extend some of those entitlements, their funding, or both beyond the broader platform of paid work. In both cases, the goal is at least two-pronged: first, to extend crucial entitlements to those who in the past would have been, but no longer are, securely ensconced within stable employment relationships; and second, to preserve jobs- that is, to counter firms' incentive to replace employees with contractors or human workers with machines.

This Article has focused mainly on the latter virtue of untying some entitlements and their costs from employment. I do not want to overstate the impact on job conservation. Having argued for a fairly cautious recalibration of the legal burdens on employment of human labor-one that aims to preserve or even expand the contours of the decent work agenda- $-\mathrm{I}$ cannot claim more than an incremental reduction in firms' incentive to offload workers. On the other hand, the strategy proposed here, unlike the fortress strategy, would help to meet both the challenge of automation and the challenge of fissuring. It would reduce firms' incentive to replace employees with either contractors or machines.

The strategy I have proposed also has the virtue of extending crucial entitlements to those who no longer work within stable employment relationships. Doing so would promote both liberty and equality. First, the

${ }^{216}$ H. W. Arthurs, The New Economy and the New Legality: Industrial Citizenship and the Future of Labour Arbitration, 7 CANADIAN LAB. \& EMP. L.J. 45, 46 (1999); see also H. W. Arthurs, Developing Industrial Citizenship: A Challenge for Canada's Second Century, 45 REV. B. CANADIEN 786 (1967). 
strategy proposed here would better enable some individuals to choose the greater autonomy and flexibility of self-employment or freelancing (even as it reduced firms' incentive to use freelancers instead of employees). It is hard to credit the rosy depictions of the so-called "sharing economy" when so many of those who work in that economy would prefer to have a real job and the relative stability and benefits that go with it. ${ }^{217}$ Yet freelance and platform-based work is not merely a sham or a last resort for those who cannot get a full-time job. Many individuals genuinely value the freedom from direct supervision and the ability to determine their own work schedule. ${ }^{218}$ Others would surely make that choice if they had a baseline level of economic security from which to do so.

I emphasize that we should not dismantle the current system of employment-based benefits, creaky and incomplete though it is, unless and until a sustainable system of more broadly socialized benefits is at hand. Efforts broadly to socialize and subsidize what have long been employee benefits will face stiff political headwinds, including powerful anti-tax and anti-redistributive impulses (even among some prospective beneficiaries), ${ }^{219}$ as well as evasive maneuvers, such as transnational tax strategies by which firms or individuals can reduce their tax exposure by offshoring operations or income. The project outlined here aims to replace the existing employment-based social model, but not, in the meantime, to undermine it.

A stronger universal system of social provision would also promote equality in two senses. It would redistribute some of the outsized gains at the top of the income distribution to those whose living standards have stagnated. And it would counter the stratification of society into insidersrelatively privileged and well-provisioned employees of leading firms-and outsiders who are left to their own devices (or to a social safety net that is politically vulnerable because of its narrow focus on the poor).

The prevailing strategy of doubling down on and shoring up the fortress of employment, however successful, will still leave out a large and almost certainly growing segment of the adult population, along with their dependents. Detached from economically capable and relatively compliant lead firms, they may work for less profitable and compliant contractor firms,

\footnotetext{
${ }^{217}$ MGI, Study on Independent Work, supra note 104, at 1. ${ }^{218} \mathrm{Id}$.

${ }^{219}$ On the politics of redistribution, see Gillian Lester, Can Joe the Plumber Support Redistribution? Law, Social Preferences, and Sustainable Policy Design, 64 TAX L. REV. 313 (2011); Gillian Lester, "Keep Government Out of My Medicare”: The Elusive Search for Popular Support of Taxes and Social Spending, in WORKING AND LIVING IN THE SHADOW OF ECONOMIC FRAGILITY (Michael Sherraden and Marion Crain eds., 2013).
} 
or as independent contractors, freelancers, temps. Or they may be unable to find steady paid work at all. A stronger set of basic social entitlements would help to ensure that those individuals and their children will enjoy the foundations of a decent and healthy life even if they cannot enter the fortress of full-time stable employment.

\section{F. Some Objections, Alternatives, and Extensions}

I have argued that a shift away from employment as the platform for entitlements and their funding, and toward more universal social entitlements and broader-based funding, would serve multiple goals. But the strategy of "unburdening" employment—even along the circumspect lines proposed here-will meet resistance from those who seek instead to fortify the existing model of worker rights and entitlements and employer responsibilities— to shore up the fortress of employment.

As suggested above, some of the resistance to unburdening employment reflects a premise, explicit or implicit, that employers deserve to bear the burden of whatever rights and entitlements workers deserve to have, including the minimum material requisites of a decent life for oneself and one's dependents. ${ }^{220}$ I share that intuition, but I have come to question it. As it becomes easier for employers lawfully to escape those burdens-partially through fissuring or altogether through automation-the premise begins to look self-defeating. It is certainly in tension with plausible concerns about the pace of automation and the prospects of net job destruction.

Other objections to the unburdening strategy are more pragmatic. One, also foreshadowed above, harkens back to the economists' mantra of creative destruction: even if high labor standards are likely to destroy some jobs, they will also help to generate new and better jobs. As Marc Linder has shown, that was the view of some New Deal proponents of early minimum wage laws. The tendency both to displace some workers and to promote more capital-intensive modes of production was viewed as a feature, not a bug, of those laws. ${ }^{221}$ As a result, both consumer demand and displaced workers would flow toward the more efficient (and capital intensive) producers who could afford to pay higher wages. ${ }^{222}$ But if this time really is different in terms of prospective net job losses—as new technologies close

\footnotetext{
${ }^{220}$ It might resonate, too, with a fulsome conception of the total cost of reproducing labor, the burden of which should arguably fall on those who use labor.

${ }^{221}$ Marc Linder, The Minimum Wage as Industrial Policy: A Forgotten Role, 16 J. LEGIS. 151 (1990).

${ }^{222}$ This was not just left to the "invisible hand" of the market; public investments in training, transition, assistance, and job creation were also part of the New Deal program, and of the recovery. See infra note --.
} 
in on most of the human capabilities that both present and future product and service markets require-we have more to worry about than the New Dealers did. ${ }^{223}$

Another argument for shoring up the fortress of employment, and against the "unburdening" strategy, is more fatalistic. Net job losses due to automation are inevitable, and will not be much affected by reducing the costs of employees' legal rights, benefits, and protections. Those costs obviously matter only at the margin in firms' decisions about automation; and cutting them back would only marginally slow down the loss of jobs while undermining the quality and working conditions in the jobs that remain. To be sure, people will not win a "race against the machines" on cost grounds, and they should not try to do so. Still, we should not imagine that the pace of automation does not matter. The faster jobs are automated, the less time people will have to acquire the skills needed in a more techinfused economy; and the less time we as a society will have to devise, build support for, and implement sensible legal and institutional responses to automation.

Underlying the last two defenses of the legal fortress of employment are conflicting predictions about the future impact of automation on jobs-one that is skeptical of the prospect of job losses and one that is resigned to them. That reminds us again of the uncertainties and contingencies that cloud our labor market forecast, which might be yet another reason to resist a broadly deregulatory response to fears of automation-induced job loss. Yet all of these arguments together do not wholly dispel the concern that labor and employment laws are contributing in some measure to the speed and extent of job losses. I have argued that it is possible to counter that impact while protecting workers' rights and interests, and at the same time to begin to construct a stronger and more inclusive foundation for the more varied working lives that are likely in the labor markets of the future.

Others might criticize the unburdening strategy proposed here, and defend existing employment rights and benefits, by touting the purported superiority of alternative policy tools for spreading the benefits and mitigating the costs of automation. Among the most salient alternatives are new or expanded forms of income support-such as a UBI or a negative income tax-and public investments in job creation and job preparation.

\footnotetext{
${ }^{223}$ For those who yearn for a post-work future, we might instead have more to gain from higher labor standards-precisely because of the tendency to accelerate automation. See, e.g., NICK SRINECK AND ALEX WILLIAMS, INVENTING THE FUTURE: POSTCAPITALISM AND A WORLD WITHOUT WORK (2015) (arguing for higher labor standards in order to accelerate the shift from paid work to a universal basic income as the foundation for individuals' material wellbeing).
} 
Richard Freeman proposes an interesting variant by which workers would acquire an equity share in technological capital, and derive part of their income from that equity. ${ }^{224}$ Given the growing disparity in returns to capital (including robots) versus labor, he contends that workers need a larger stake in the latter as one source of income.

This is not the place to thoroughly evaluate all of these alternative policies. I will note that some of them blend into, and others are entirely compatible with, the proposals I have made here. And I do not believe they undermine this Article's basic case for shifting some of the entitlements and burdens that are currently linked to employment to a broader set of beneficiaries and a broader funding base. For example, a UBI or its equivalent would help people weather-or even choose-breaks or shortfalls in paid employment, or choose independent work beyond employment. It would also redistribute some of the gains from automation from the economic winners to the losers. It is striking that Andy Stern, a former trade-union leader, emerged from a deep dive into the study of the impact of technology on the future of work as a proselytizer for a UBI. He concluded it was a necessary response to a foreseeable future of massive job destruction through automation. ${ }^{225}$ The case for a UBI is currently hotly contested and faces daunting political odds. But the case will undoubtedly grow stronger and gain adherents if job losses begin to mount. A UBI is not incompatible with the strategy proposed here, but unless these new income entitlements also replace or reduce the burden of some employer mandates, they would not have the job preservation benefits of the strategy I have proposed. Any moves toward supplementing wage-based income should be designed to slow as well as to cushion job losses.

Another alternative response to the challenge of automation is investments in job creation and job preparation. Public investments in physical infrastructure and in social services for people-especially young, old, and disabled people-who cannot afford to buy the care they need in the market would both create jobs and meet societal needs. ${ }^{226} \mathrm{~A}$ program of

\footnotetext{
${ }^{224}$ Richard Freeman has proposed that, in view of the seemingly abiding shift in the distribution of income away from labor and toward capital (and robots), this income support might be derived from workers' ownership of sizable chunks of technological capital. Freeman, supra note 7, at 1.

${ }^{225}$ See STERN \& KRAVITZ, supra note 3.

${ }^{226}$ On the economic and social value of public investments in caregiving and early childhood education, see Nina Dastur et al., Building the Sharing Economy: Workforce Investments to Expand Access to Affordable, High-Quality Early and Long-Term Care, GeO. CTR. ON POVERTY AND INEQ., (2017), https://www.georgetownpoverty.org/wp-content/uploads/2017/05/Building-thecaring-economy_hi-res.pdf [https://perma.cc/9ZTM-UZZZ].
} 
national service-voluntary or even mandatory - would do both of those things and perhaps more. ${ }^{227}$ Better institutions of basic and higher education and vocational training and retraining, for their part, would help equip people for the technology-adjacent jobs that are likely to grow in the future. These institutions would also allow more people to benefit from the gains that automation will produce. ${ }^{228}$

Again, the question is not the value or even the necessity of these reforms but their sufficiency. Investments in jobs and training make eminent good sense, but alongside rather than instead of the strategy of shifting some employment benefits from the "platform" of employment and onto a broader tax base and to a more universal coverage formula. Public job creation and job training will not address the growing coverage gap that arises from fissuring and the proliferation of independent work outside the employment nexus, nor will they serve the liberty and equality interests that a more universal system of social benefits would advance. Pursuit of those policies should supplement, not substitute, a recalibration of employment mandates, benefits, and liabilities.

One final alternative strategy warrants discussion: a forced reduction in working hours. Matthew Dimick argues that tighter regulation of working hours would more equitably spread both work and leisure. ${ }^{229} \mathrm{He}$ frames his proposal as an alternative to the UBI, but it might also be seen as an alternative response to automation-related job losses. The proposal has real virtues, though they do not include work preservation-tighter regulation of hours (in the form of either an hours cap or an overtime premium) would likely raise the hourly cost of labor and strengthen the case for automation.

${ }^{227}$ Apart from supplying valuable paid work opportunities and work experience, “a vastly expanded, even mandatory, national service program ... might at once throw Americans of every creed and culture together for a year or two at an impressionable age, fire up civic engagement and even revive the American dream.” See Roger Cohen, Travel Abroad, in Your Own Country, N.Y. TimEs (March 4, 2017), https://www.nytimes.com/2017/03/04/opinion/sunday/travel-abroad-in-your-owncountry.html?_r=0 [https://perma.cc/G5Y2-VDPJ].

${ }^{228}$ Notably, the MGI report, Jobs Lost, Jobs Gained, supra note 60, urges measures like these. So, too, the New Dealers who embraced the tendency of higher labor standards to destroy some jobs, see infra ---, also urged the adoption of an "active manpower policy," including investments in "retraining and education ... and public employment," so that displaced workers did not bear the burden of these shifts. Linder, supra note 221, at 158-59. Indeed, the expansion of social programs and regulatory activity since the New Deal—and the resulting growth of public employment at all levels of government - might have offset some of the labor market slack created by automation over the past eight decades, whether or not it was intended to do so.

${ }^{229}$ See Dimick, supra note 9. 
(The impact on labor costs would be even greater, of course, if shorter hours were to be achieved without lowering incomes, as past movements for shorter working hours sought to do.) That should by no means end the discussion. A shorter workweek (as well as universal rights to paid leave and vacation) would be a highly desirable response to an overall decline in the amount of paid work in the economy; it might well become part of our evolving conception of "decent work." But as with other aspects of "decent work," we should still ask whether it is possible to vindicate that entitlement while shifting part or all of its costs away from both workers and those who deploy their labor and onto a broader funding base.

\section{Conclusion}

The claim that machines will make human labor obsolete is both overstated and often stated. It is a refrain that has surfaced periodicallyoften with the addendum that "this time is different"—only to be buried by the next wave of economic growth. History is largely on the side of those enthusiasts of innovation and markets who reject or ridicule predictions of a jobless future. And yet sometimes the future actually is different from the past. For example, consider Malthus, who at the close of the eighteenth century extrapolated from a long history of stagnant productivity to predict that a growing population would inevitably outstrip society's nearly fixed food supply. ${ }^{230} \mathrm{He}$ was proven spectacularly wrong by the Industrial Revolution. ${ }^{231}$

We might now face a future of shrinking employment opportunities and falling wages for workers whose skills are rapidly being replicated or surpassed by ever-smarter and more cost-effective machines. Given current social and economic arrangements, that is a devastating prospect for the vast majority of people in our society who depend on paid work for their livelihood and the material support of their dependents. And it is a profoundly unsettling prospect for a society in which so many dimensions of personal identity, social integration, and civil society—as well as economic security - are intertwined with paid work. For now and for the near future, decent work for those who want and need it-whether it is within or beyond the employment relationship—remains a worthy aspiration. ${ }^{232}$

\footnotetext{
${ }^{230}$ Thomas Robert Malthus, An Essay on the Principle of Population (Joyce E. Chaplin ed., W.W. Norton \& Co. 2018) (1798)

${ }^{231}$ SYlVIA NASAR, GRAND PURSUIT: THE STORY OF ECONOMIC GENIUS (2011).

232 That fight might proceed under the banner of a "right to work," see supra notes $140-142$, but that is a complex question. See, for example, Hugh Collins's elucidation of several ambiguities, contradictions, or vagaries in existing conceptions of the so-called right to work, and his response to those difficulties. Hugh Collins, Is There a Human Right to Work?, in THE RIGHT TO WORK, supra note 141, at XX.
} 
For some readers, the threat of automation to the future of work calls for much more drastic responsive measures. Recalibrating employment mandates and benefits, even if supplemented by policies of income support, training, and job creation, may appear timid and insufficient to meet the coming crisis. Why not affirmatively subsidize human labor and job creation? Or why not tax job-destroying technology, or regulate and restrict its deployment? Or-if the technological destruction of middle-class jobs is precipitating the end of capitalism as we know it, as some scholars contend $^{233}$ - why not begin to grapple with the infinitely larger challenge of building the foundations for a new political economy that is not centered on private profits and paid work? Some of these questions will loom larger if the facts on the ground begin to point decisively toward growing automation-based unemployment. In particular, the notion of subsidizing human work, and affirmatively supporting firms' creation and maintenance of decent jobs, bears closer scrutiny than I have given it here. But we need to start somewhere, even in a context of uncertainty and intense debate about the future impact of automation on labor markets. The strategy that I have proposed can preserve decent jobs, or slow their loss, while simultaneously laying the foundations for a future beyond employment.

There is a certain irony in the almost romantic attachment of some contemporary worker advocates to the standard employment relationship, with its signature features of worker dependency and managerial domination. In the early decades of industrialization, skilled artisans fought desperately to retain their autonomy, resisting the subordination and dependency that came with what they called "wage slavery." 234 Eventually most workers and their organizations resigned themselves to the subordinate role of employee, and fought for its reformation through an array of employee rights, minimum labor standards, and structures for collective representation-all to the end of transforming "wage slavery" into a decent way of economic life for ordinary workers. But we should not assume that the standard employment relationship, thus civilized, is a permanent reality for most workers, much less an ideal to defend at all costs.

Through fissuring and automation, firms are increasingly finding ways to escape their end of the socially constructed deal embodied in the standard

\footnotetext{
${ }^{233}$ See Collins, supra note 232.

${ }^{234}$ See William E. Forbath, The Ambiguities of Free Labor: Labor and the Law in the Gilded Age, 1985 WIS. L. REV. 767, 769 (1985); Elizabeth Anderson, Liberty, Equality, and Private Government, Lecture at Princeton University (Mar. 4-5, 2015) in TANNER LECTURES ON HUMAN VALUES 63, 86, https://tannerlectures.utah.edu/Anderson\%20manuscript.pdf [https://perma.cc/KY8Q-V5L8].
} 
employment relationship. And a growing number of workers are either fleeing or being ejected from both the constraints and the protections of that relationship. Shoring up and expanding the fortress of employment will not prevent that exodus. We do need to improve and enforce employee rights and labor standards - those that are necessarily tied to employment and employer practices. We need to invest public resources in creating new jobs and better preparing people for the jobs of the future. But we also need to furnish the growing domain that lies beyond employment with the minimum basic necessities of a decent life both for those who choose a more independent economic existence and for those who cannot get into the fortress.

In his prescient 1999 report to the European Commission, Alain Supiot observed that "the employee subject to full-time, open-ended subordination is surely not the only model for working life. Another figure can be discerned on the horizon: a worker who can reconcile security and freedom." 235 Perhaps the real, if sometimes exaggerated, threat of automation-based job losses will supply the motivation we need to move toward a new social model—one that "reconcile[s] security and freedom," that supports many modes of working life, and that works better for all of those who work for a living.

${ }^{235}$ See SUPIOT, supra note 214, at 57. 